\title{
Application of High-Strength Lightweight Concrete in Gob-Side Entry Retaining in Inclined Coal Seam
}

\author{
Daoyong Zhu, ${ }^{1,2}$ Weili Gong $\mathbb{D}^{1,2}$ Yi Su $\mathbb{D}^{1,2}$ and Aipeng Guo $\mathbb{i D}^{1,2}$ \\ ${ }^{1}$ State Key Laboratory of Geomechanics \& Deep Underground Engineering, China University of Mining \& Technology, \\ Beijing 100083, China \\ ${ }^{2}$ School of Mechanics and Civil Engineering, China University of Mining \& Technology, Beijing 100083, China
}

Correspondence should be addressed to Yi Su; suyicumtb@126.com

Received 12 October 2019; Revised 3 December 2019; Accepted 19 December 2019; Published 22 January 2020

Academic Editor: Antonio Caggiano

Copyright ( 12020 Daoyong Zhu et al. This is an open access article distributed under the Creative Commons Attribution License, which permits unrestricted use, distribution, and reproduction in any medium, provided the original work is properly cited.

Gob-side entry retaining (GSER) is a popular no-pillar mining technology that can increase coal recovery rate. We propose the application of high-strength lightweight (HSLW) concrete to construct the gob-side support body (GSSB) in NO. 411 inclined working face of Jingang Coal Mine. Firstly, the mechanical model of retained roadway was established, and the calculation for limit angle of GSSB stability and support resistance was mathematically derived. Using the performance test, the optimal proportion of LC50 concrete was determined as follows: the water-binder ratio was 0.3 ; the silica fume dosage was not more than $10 \%$; the fly ash dosage was $10-20 \%$; and the sand ratio was $0.45-0.50$. Based on theoretical deduction and laboratory analysis, the width of GSSB was obtained to be $0.75 \mathrm{~m}$, and the optimal arrangement of concrete blocks with "two longitudinal and one horizontal, crisscross, and staggered joints" was determined. FLAC3D software was used to study the influence of different widths and material strengths on the surrounding rock deformation and verify the reasonable width and strength of the designed GSSB. Finally, field monitoring of retained roadway shows that the deformation is controlled in a small range, and the retained roadway effect is better, thus proving the feasibility of HSLW for constructing the support body for GSER. Our findings can serve as a theoretical guide for safety and effective implementation of HSLW as GSSB.

\section{Introduction}

Gob-side entry retaining (GSER) is the most widely used nopillar mining technology at present [1-4]. It can increase the coal recovery rate, reduce the tunneling rate, and avoid large losses of coal resources. Although its technical advantages and economic benefits are remarkable [5-7], it also has obvious disadvantages. For example, the construction cost of "high-water material" filling wall of advanced formwork is relatively high $[2,8]$. Because its construction is complex and time-consuming, the mining and development replacement is tense [9]. In addition, traditional backfilling materials such as concentrated props, gangue walls, and wood crib have low support strength and poor impact resistance and are liable to cause large deformation and other issues. Moreover, the field operation process of this technology tends to be mature, and the movement of rock strata is beyond the control of mining practitioners $[10,11]$. To reduce the deformation and improve the stress state of the surrounding rock, the material properties of gob-side support body (GSSB) should be studied in depth $[12,13]$.

Significant studies on the material and mechanical properties of GSSB have been conducted. Tan et al. [14] designed a new type of artificial composite wall named "flexiblehard" that can both endure large compression and provide strong support. Liu et al. [7] conducted an experimental study on the creep characteristics of GSSB with high-water material by using the large-scale creep test system developed by themselves. They found out that there are three creep stages of failure, and the creep limit load of GSSB increased with the decrease in the water-cement ratio of the high-water rapid-setting material. Wang et al. [15] proposed a new technology for GSER: concrete-filled steel tube piers as support, and tested their bearing capacity. The 
criterion of bearing capacity and roadway stability is then studied. However, the abovementioned studies used specific engineering and geological conditions in establishing mechanical models to analyze the surrounding rocks and were designed in terms of material and mechanical properties of GSSB [16, 17]. However, the completed construction method of GSER under other geological conditions cannot be directly applied, but to learn its successful experience. It should be combined with the geological situation of coal seam, economy, time, manpower, and other factors; finally, a new method of retaining roadway can be designed [18-20].

This study focuses on the GSER of NO.-411 working face of Jingang Mine. Due to the following advantages: high bearing capacity, simple processing, low cost, and simple wall construction, we propose the use of high-strength lightweight (HSLW) concrete to construct a GSSB in an inclined coal seam. Using theoretical analysis and numerical simulation, we analyzed the surrounding rock movement law of retained roadway, established the mechanical model of supporting resistance, and designed the HSLW concrete masonry wall. Finally, field application and verification are carried out. Our study contributes to a greater understanding of the development of GSER technology in inclined coal seam.

\section{Analysis of Engineering Situation}

2.1. Engineering and Geological Conditions. Figure 1(a) shows the geographical situation; the coal mine is located in Meizhou City, Sichuan Province. Figure 1(b) shows the layout of the working face; the length of the test section is $700 \mathrm{~m}$. The dip angle of the coal seam is $27^{\circ}-34^{\circ}$ with an average of $31^{\circ}$. The buried depth is about $450 \mathrm{~m}$; the thickness of coal seam is $1.63-2.3 \mathrm{~m}$, averaging $1.4 \mathrm{~m}$; and the mining height is $2.8 \mathrm{~m}$. The coal has two layers: the upper coal seam is $0.85 \mathrm{~m}$ thick on average, and the lower coal seam, $1.4 \mathrm{~m}$. They are separated by a mudstone interlayer, $0.55 \mathrm{~m}$ thick. With a mining height of $2.8 \mathrm{~m}$, two coal seams are mined simultaneously. The immediate roof is black siltstone, $2.3 \mathrm{~m}$ thick on average; the main roof is sandy mudstone, $1.7 \mathrm{~m}$; the direct floor is sandy mudstone, $0.5 \mathrm{~m}$; and the main floor is deep gray mudstone, $3.5 \mathrm{~m}$. Figure 1 (c) shows the geological column of the working face, and Figure 1(d) shows the section map of the roadway.

\subsection{Analysis of Mechanical Model}

2.2.1. Stability Analysis of Gob-Side Support Body. Figures 2(a) and 2(b) illustrate the force model of the GSSB in the initial stage-when the roof does not break and collapse-and the later, stable stage-when the roof breaks and collapses, starting to compress the support body. It is constructed along the floor of the coal seam with roadway on one side and gob on another. When the dip angle of the coal seam is small, GSSB is relatively stable; however, increasing the dip angle leads to GSSB sliding and flipping due to deadweight. This becomes more pronounced when the immediate roof has not yet collapsed. Because it is not pressed by the overlying stratum, GSSB is very much prone to slide. Therefore, stability analysis of GSSB is an important consideration.

Static equilibrium analysis is performed on Figure 2(a), and the critical condition for the GSSB to not slide is

$$
G \sin \alpha<\mu G \cos \alpha
$$

The moment analysis is performed at the initial stage, and the critical condition for the supporting body to not to dumping is

$$
G \sin \alpha \frac{h}{2}<G \cos \alpha \frac{b}{2}
$$

where $G$ is the deadweight of the supporting body, $\mathrm{kN} ; \alpha$ is the dip angle, ${ }^{\circ} ; \mu$ is the static friction coefficient; $h$ is the height of GSSB, $\mathrm{m}$; and $b$ is the width of GSSB, $\mathrm{m}$.

Simplifying equations (1) and (2), the range of the dip angle is

$$
\begin{aligned}
& \alpha<\arctan \mu, \\
& \alpha<\arctan \frac{b}{h} .
\end{aligned}
$$

The ratio between the width and the mining height should not be less than 0.5 , and the friction coefficient is generally between 0.5 and $0.8[17,21]$. From equation (3), we can conclude that, to prevent GSSB from sliding and flipping, the coal seam dip should be less $26.5^{\circ}-38^{\circ}$. From equation (4), the dip angle $\alpha$ is less than $26^{\circ}$. Therefore, the limit angle is $26^{\circ}$ when the dip angle is greater than the limit dip angle, $\alpha$. Measures should be taken to increase the stability of GSSB.

In Figure 2(b), for GSSB to not slide, the following should be satisfied:

$$
\begin{aligned}
\mu(Q+G \cos \alpha) & \geq T_{1}+G \sin \alpha, \\
Q \frac{b}{2}+Q \mu h+G \cos \alpha \frac{b}{2} & \geq T_{1} \frac{h}{2}+G \sin \alpha \frac{h}{2},
\end{aligned}
$$

where $T_{1}$ is the thrust of gangue in gob, $\mathrm{kN}$, and $\mathrm{Q}$ is the roof pressure, $\mathrm{kN}$.

Roof pressure $Q$ and thrust $T_{1}$ can be estimated using field geological conditions, and then a reasonable dip angle can be obtained, and equations (5) and (6) must be satisfied. Only in this way can the stability of the GSSB in the later period be guaranteed.

From the above analysis, although GSSB has great antisliding force and antidumping moment in the later stage, it is significantly affected by mining and roof activity. Therefore, it is necessary to strengthen the monitoring of GSSB to ensure its stability and prevent it from sliding and flipping.

2.2.2. Analysis of Support Resistance. The support resistance has a great influence on the rotation subsidence of the overlying strata. Reasonable support resistance can change the fracture location of roof, thus affecting the fracture law of upper strata. To calculate the support resistance, Han et al. [8] simplified the roof strata into "superimposed slabs," and the binding force between the slabs was not considered. 


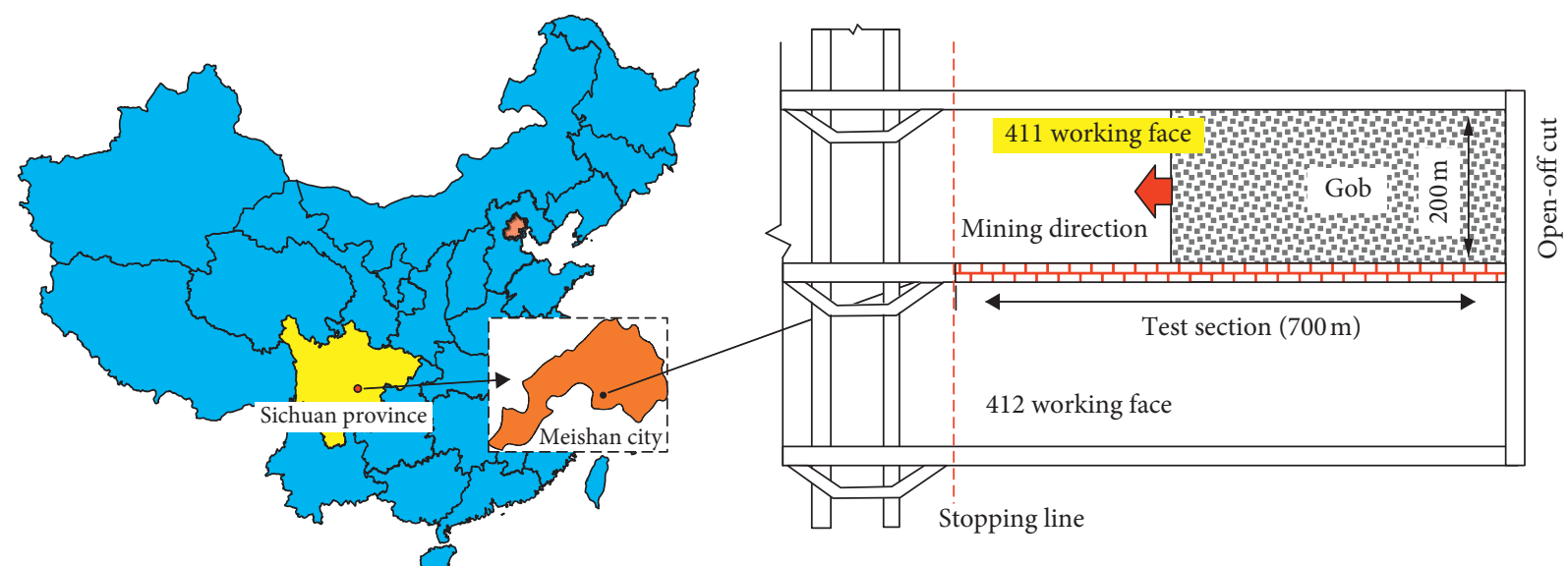

(a)

\begin{tabular}{|c|c|c|}
\hline Histogram & Thickness (m) & Lithology \\
\hline & 13.2 & Medium sand \\
\hline & 6 & Mudstone \\
\hline & 1.7 & Sandy mudstone \\
\hline & 2.3 & Siltstone \\
\hline & 0.85 & Coal \\
\hline & 0.55 & Mudstone \\
\hline & 1.4 & Coal \\
\hline & 0.5 & Sandy mudstone \\
\hline & 3.5 & Mudstone \\
\hline & 8.5 & Medium sand \\
\hline
\end{tabular}

(c) (b)

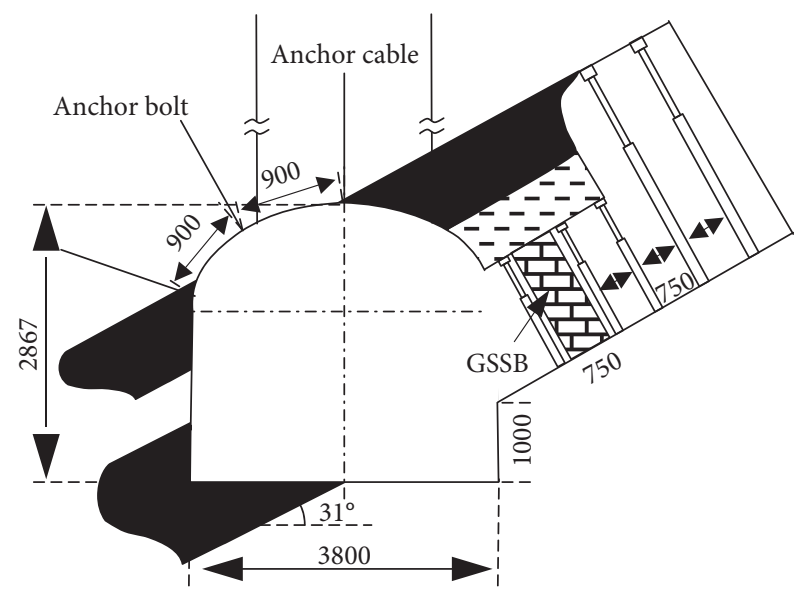

(d)

Figure 1: Engineering conditions. (a) Geographical situation, (b) working face layout, (c) geological column of working face, and (d) retained roadway support section.

Figures 3(a) and 3(b) show the simplified mechanical model of GSER and the single-layer roof failure model, respectively. The shaded part represents the load jointly borne by the roadway support and the roadside support. The maximum bending moment of the rectangular plate is in the middle part. We focus on the unit width slab at the maximum part of bending moment, marked by red dotted lines in Figure 3(b) and simplified to $\mathrm{OO}^{\prime} \mathrm{ABCD}$ beam structure.

Figure 4 shows the mechanical model of the first roof. $\mathrm{OB}$ and $\mathrm{CD}$ segments are affected by the force of the roof and the weight load, respectively.
The calculation of support resistance begins with the first roof stratum. From Figure 4, the support resistance of the first layer is calculated as follows [8]:

For $\mathrm{AB}$,

$$
\begin{aligned}
& \sum F_{y}=0, \quad F_{\mathrm{Q} 1}-q L_{1}=0, \\
& \sum M=0, \quad 2 M_{P 1}-\frac{q_{1} L_{1}^{2}}{2}=0 .
\end{aligned}
$$

For OA, 


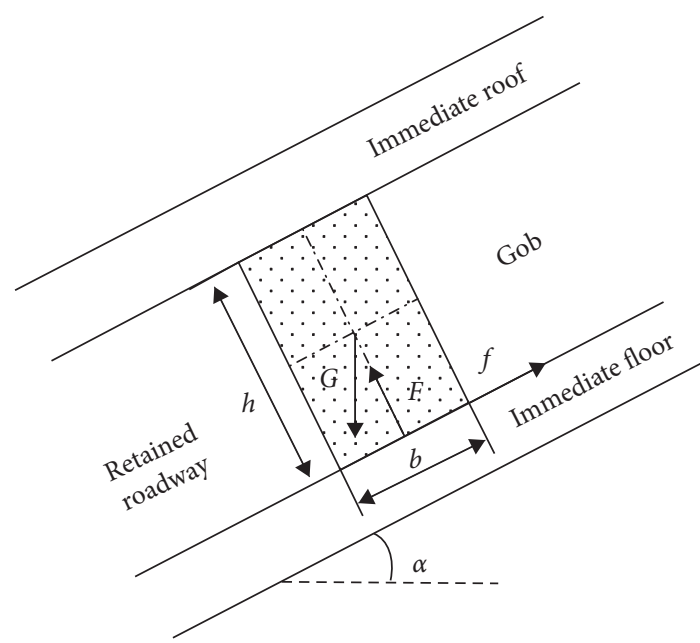

(a)

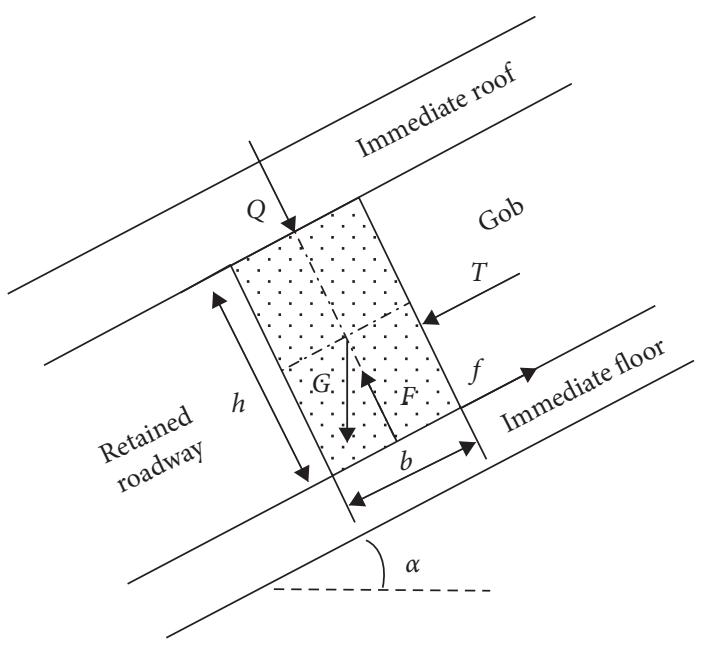

(b)

Figure 2: Force model of GSSB. (a) Initial stage and (b) later stage.

$$
\sum M=0, \quad P_{1} \frac{x+a+(b / 2)}{\cos \alpha}+\frac{x}{2} F_{o}^{\prime}+M_{O 1}-M_{P 1}-F_{Q 1}(x+a+b)-\frac{q_{1}}{2}(x+a+b)^{2}=0 .
$$

The simultaneous equations (1)-(3) are solved:

$$
P_{1}=\frac{\left[M_{P 1}+q_{1} L_{1}(x+a+b)+\left(q_{1} / 2\right)(x+a+b)^{2}-M_{O 1}-(x / 2) F_{o}^{\prime}\right] \cos \alpha}{x+a+(b / 2)},
$$

where $a$ is the roadway width; $b$ is the width of GSSB; $x$ is the width of the loose zone of solid coal; $L_{a}$ is the length of the working face; $L_{b}$ is the weighting step distance of the working face; $P_{1}$ is the minimum support resistance required, $\mathrm{N}$; and $M_{P 1}$ is the maximum bending moment when roof strata breaks, $\mathrm{N} \cdot \mathrm{m}$. Under the limit condition, $M_{P 1}=M_{O 1} ; q_{1}$ is the self-weight load collection degree of the first floor roof beam, $\mathrm{N} / \mathrm{m}^{2} ; L_{1}$ is the characteristic size of rock fracture, $\mathrm{m}$; $M_{\mathrm{O} 1}$ is the bending moment of roof strata, $\mathrm{N} \cdot \mathrm{m} ; F_{o}^{\prime}$ is the support force of solid coal to the roof, $\mathrm{N} ; F_{\mathrm{Q1}}$ is the shear force of the broken roof beam, $\mathrm{N}$; and $\alpha$ is the dip of the coal seam.

Similarly, the roof cutting support resistance of the $m$-th floor is as follows:

$$
P_{m}=\left[M_{P m}+\sum_{i=1}^{m} F_{Q i}\left(x+a+b+\sum_{i=0}^{m-1} \frac{h_{i} \sin \theta_{i}}{\cos \left(\theta_{i}+\alpha\right)}\right)+\sum_{i=1}^{m} \frac{\gamma_{i} h_{i}}{2 \cos \alpha}\left(x+a+b+\sum_{i=0}^{m-1} \frac{h_{i} \sin \theta_{i}}{\cos \left(\theta_{i}+\alpha\right)}\right)^{2}-\sum_{i=1}^{m} M_{O i}-\frac{x}{2} F_{o}^{\prime}\right] \cos \frac{\alpha}{x}+a+\frac{b}{2}
$$

From the above analysis, the support resistance produced by GSSB can be estimated. This can avoid damage from compression deformation of the support body, due to the support resistance not being up to standard, and prevent the waste of material caused by the excessive support resistance.

2.2.3. Analysis of Compressible Deformation. When the working face is mined, the overlying roof of the retained roadway is broken, and subsequently, it rotates and sinks. This produces a certain degree of compression deformation for GSSB [22]. The compression deformation caused by subsidence cannot be interfered artificially. Therefore, the GSSB should have certain compressible deformation characteristics to avoid the damage caused by stiffness. The calculation model of compressibility of GSSB is shown in Figure 5.

From Figure 5, the compression of GSSB can be obtained as follows:

$$
\begin{aligned}
\Delta S & =h_{a}-h_{b}\left(k_{c}-1\right), \\
S_{c} & =\frac{L_{0} \Delta S}{L}=\frac{(x+a+0.5 b) \Delta S}{L},
\end{aligned}
$$




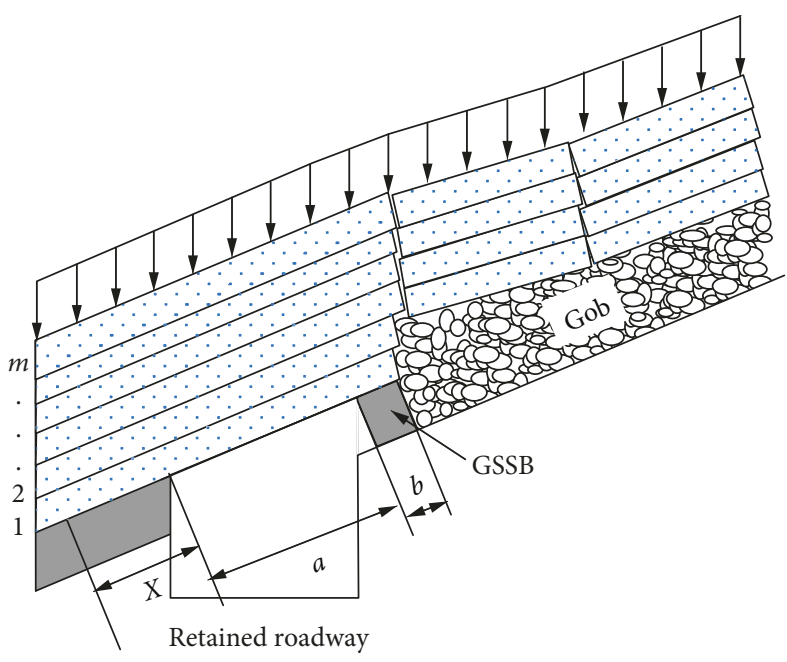

(a)

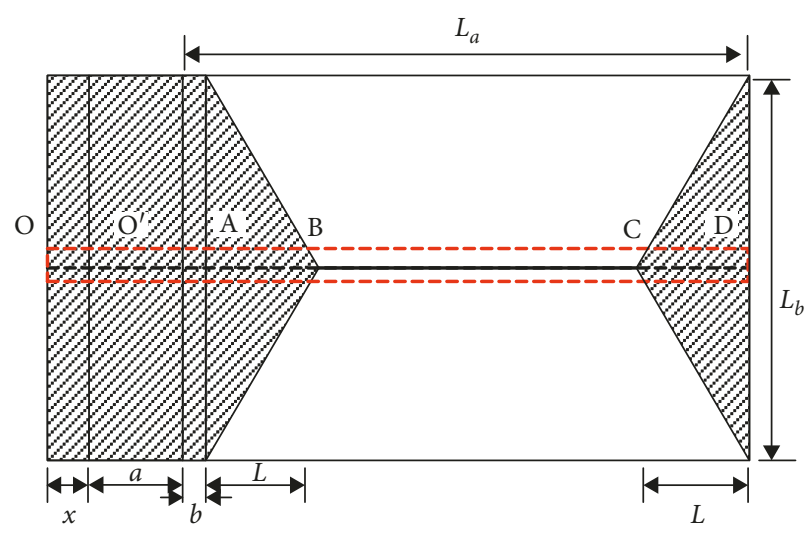

(b)

FIGURE 3: Roof force model. (a) Simplified mechanical model of GSER and (b) single-layer roof failure model.

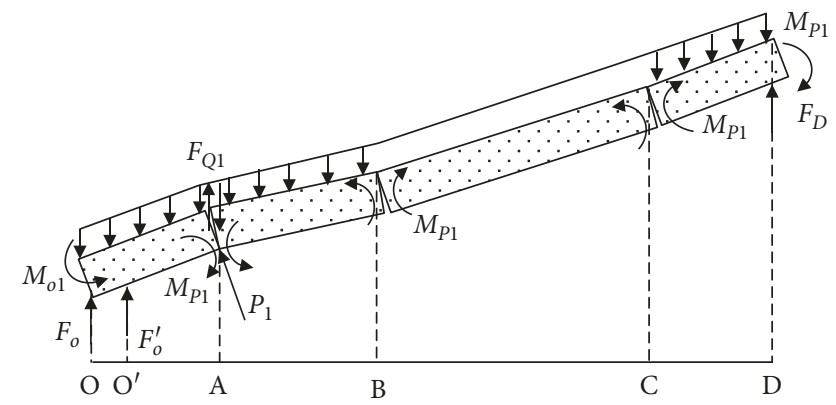

Figure 4: Failure model of beam structure.

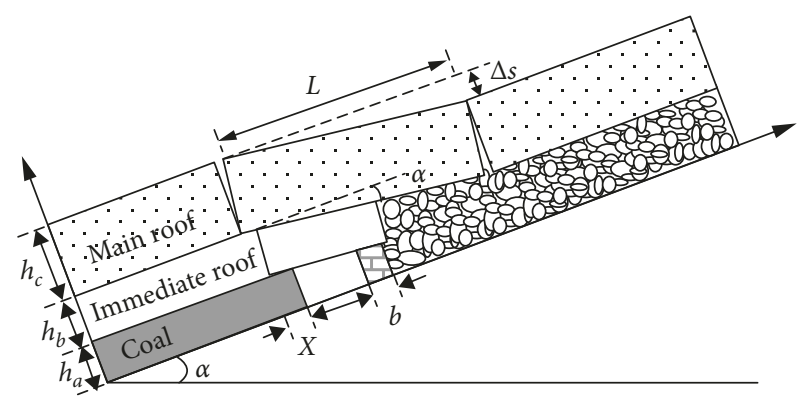

FIgURE 5: Compressibility model of GSSB.

where $S_{c}$ is the amount of compression for GSSB, $\mathrm{m} ; \Delta S$ is the amount of rotary subsidence of the main roof, $\mathrm{m} ; h_{a}$ is the mining height, $\mathrm{m} ; h_{b}$ is the immediate roof thickness, $\mathrm{m}$; $h_{c}$ is the main roof thickness, $\mathrm{m}$; $k_{c}$ is the broken expansion coefficient of rock mass; $x$ is the horizontal distance from the basic breaking point of the main roof to the solid coal wall, $\mathrm{m} ; a$ is the width of the roadway, $\mathrm{m} ; b$ is the width of the GSSB, $\mathrm{m} ; L$ is the main roof lateral fracture length, $\mathrm{m}$; and $L_{0}$ is the distance from the solid coal fracture line to the center of GSSB, m.

The main roof lateral fracture length $L$ is generally determined by the inclination width and periodic weighting length [6]:

$$
L=\frac{2 d}{17}\left[\sqrt{\left(10 \frac{d}{S}\right)^{2}+102}-10 \frac{d}{S}\right],
$$

where $S$ is the width of working face, $\mathrm{m}$, and $d$ is the periodic weighting length, $\mathrm{m}$.

Through the calculation of stability, support resistance, and compressible deformation, the basic mechanical parameters of GSSB can then be estimated, providing reference data for the experiment and field design.

\section{Gob-Side Support Body Design}

3.1. Performance Test of High-Strength Lightweight Concrete. The GSSB is made of LC50 HSLW concrete blocks. This section investigates the mechanical properties of the mix ratio of this concrete through laboratory experiments.

3.1.1. Selection of Concrete Material. The concrete preparation test utilized the following raw materials: 42.5 grade ordinary Portland cement with a density of $3.15 \mathrm{~g} / \mathrm{cm}^{3}$, silica fume with a density of $2.2 \mathrm{~g} / \mathrm{cm}^{3}$ and an average particle size of $0.18 \mathrm{~m}$, and Class II fly ash with a specific surface area of $380 \mathrm{~m}^{2} / \mathrm{kg}$. Fine aggregate is medium-coarse river sand with a fineness modulus of 2.7-2.8 and mud content less than $1 \%$. A high-range water reducing agent is selected as the admixture $[23,24]$. The lightweight aggregate uses 800 -grade crushed stone expanded shale ceramsite. The performance parameters are shown in Table 1.

3.1.2. Orthogonal Experimental Design. An orthogonal array test is suitable for use when multifactor and multilevel characteristics are studied [25]. Orthogonal table L9 $\left(3^{4}\right)$ was selected as shown in Table 2. NO. 9 represents the number of orthogonal tests; NO. 3, the level number; and NO. 4, the number of experimental factors. 
TABLE 1: Main properties of lightweight aggregates.

\begin{tabular}{lcccccc}
\hline $\begin{array}{l}\text { Lightweight } \\
\text { aggregate }\end{array}$ & $\begin{array}{c}\text { Bulk density } \\
\left(\mathrm{kg} / \mathrm{m}^{3}\right)\end{array}$ & $\begin{array}{c}\text { Particle density } \\
\left(\mathrm{kg} / \mathrm{m}^{3}\right)\end{array}$ & $\begin{array}{c}\text { Cylindrical compressive } \\
\text { strength }(\mathrm{MPa})\end{array}$ & $\begin{array}{c}\text { Water } \\
\text { absorption }(\%)\end{array}$ & $\begin{array}{c}\text { Porosity } \\
(\%)\end{array}$ & $\begin{array}{c}\text { Maximum grain } \\
\text { size }(\mathrm{mm})\end{array}$ \\
\hline $\begin{array}{l}\text { 800-grade shale } \\
\text { haydite }\end{array}$ & 770 & 1420 & 7.6 & 4.3 & 54.2 & 16 \\
\hline
\end{tabular}

The water-binder ratio, volume rate of sand, fly ash content, and silica fume content are considered as four factors. $K_{\mathrm{mi}}$ is the sum of index values corresponding to the number $I$ in column $m$; $R$ is the range; and $R_{\mathrm{m}}$ is the maximum minus the minimum of the $K$ values in the $m$-th column. $R$ is used to measure the effect of corresponding factors in the test. Having a large range means that the factor exhibits significant influence, whereas factors with small range mean that they are insignificant.

$\mathrm{A}$ is the water-cement ratio with three levels, namely, 0.28 , 0.30 , and 0.32 , selected for proportioning design, and $\mathrm{B}$ is the volume. The proportioning design is carried out at $0.4,0.45$, and 0.5 levels. $\mathrm{C}$ is the content of fly ash. When the concrete strength grade is greater than LC25, the fly ash incorporation rate should be between $10 \%$ and $20 \%$ [23]; therefore, we used the following rates: $10 \%, 15 \%$, and $20 \%$. D is the content of silica fume. Three levels, $0 \%, 5 \%$ and $10 \%$, are used as the mixing ratio.

3.1.3. Experimental Results. From the orthogonal experimental design, nine concrete mixing schemes with different water-binder ratios, volume sand ratios, fly ash content, and silica fume content were studied. The slump, density, and compressive strength of concrete with nine mixing schemes were determined, and the results are presented in Table 3.

(1) Slump of Concrete. Figure 6 shows the results of concrete slump. Combined with Table 3 , the range $R$ of water-binder ratio, sand ratio, and fly ash content is stable between 10 and 20 , whereas the range $R$ of silica fume content is 29 . We can infer that slump is only slightly affected by water-binder ratio, sand ratio, and fly ash content, but the silica fume content is a relatively significant factor. Table 4 shows the analysis of variance. The $\mathrm{F}$ values of all the four factors are less than the $\mathrm{F}$ critical value, i.e., the four factors have no significant impact on the slump results. However, the $F$ value of the silica fume is larger than those of the other three factors. Therefore, relatively, the content of silica fume is the main factor affecting the slump. Therefore, the primary and secondary factors affecting slump were DACB. Higher silica fume content leads to lower concrete slump, and decrease in slump results in decrease in concrete fluidity. Therefore, the optimal mix ratio is $\mathrm{A}_{3} \mathrm{~B}_{2} \mathrm{C}_{3} \mathrm{D}_{1}$.

(2) Density Analysis. As seen in Figure 7 and Table 3, the range $R$ of both the water-binder ratio and fly ash content is notably smaller than the other two factors. The maximum range of silica fume content is 259 , and sand ratio, 185 . Moreover, as seen from Table 5, the $F$ values of the silica fume and sand rate are greater than the $F$ critical value; i.e., these factors have a significant influence on the density. Therefore, the order of influence on concrete density is silica fume, sand
TABLE 2: Orthogonal table $\mathrm{L}_{9}\left(3^{4}\right)$.

\begin{tabular}{|c|c|c|c|c|}
\hline \multirow{2}{*}{ Test number } & \multicolumn{4}{|c|}{ Factors } \\
\hline & A & $\mathrm{B}$ & $\mathrm{C}$ & $\mathrm{D}$ \\
\hline 1 & I & I & I & I \\
\hline 2 & I & II & II & II \\
\hline 3 & I & III & III & III \\
\hline 4 & II & I & II & III \\
\hline 5 & II & II & III & I \\
\hline 6 & II & III & I & II \\
\hline 7 & III & I & III & II \\
\hline 8 & III & II & I & III \\
\hline 9 & III & III & II & I \\
\hline I & $K_{\mathrm{AI}}$ & $K_{\mathrm{BI}}$ & $K_{\mathrm{CI}}$ & $K_{\mathrm{DI}}$ \\
\hline II & $K_{\mathrm{AII}}$ & $K_{\mathrm{BII}}$ & $K_{\mathrm{CII}}$ & $K_{\mathrm{DII}}$ \\
\hline III & $K_{\text {AIII }}$ & $K_{\text {BIII }}$ & $K_{\mathrm{CIII}}$ & $K_{\text {DII }}$ \\
\hline $\mathrm{R}$ & $R_{\mathrm{A}}$ & $R_{\mathrm{B}}$ & $R_{\mathrm{C}}$ & $R_{\mathrm{D}}$ \\
\hline
\end{tabular}

ratio, fly ash, and water-cement ratio, namely, DBCA. Silica fume can effectively reduce the density and improve the strength of concrete; hence, it is an essential component in the preparation of LC50 HSLW concrete. Because increasing the sand ratio increases density, sand ratio should be reasonably controlled. Therefore, the optimal mix ratio is $\mathrm{A}_{3} \mathrm{~B}_{1} \mathrm{C}_{3} \mathrm{D}_{3}$.

(3) Compressive Strength. Figure 8 shows the results of compressive strength. The range of fly ash content is the smallest, whereas the water-binder ratio is the largest. The compressive strength of concrete decreases with the increase in the water-binder ratio, from level I to level III, with the largest reduction being from level I to level II. According to the analysis of variance in Table 6, the four factors have no significant effect on the compressive strength, but the $F$ value of the water-binder ratio is the largest. Therefore, the order of influence on concrete strength is water-binder ratio, silica fume, sand ratio, and fly ash, i.e., water-binder ratio has a decisive influence on concrete strength. Therefore, the optimal mix ratio obtained by orthogonal experiment is $A_{1} B_{3} C_{1} D_{2}$.

Based on the previous test results, the optimum mixing scheme is obtained as follows: water-binder ratio is 0.30 ; silica fume dosage is not more than $10 \%$; fly ash dosage is $10-20 \%$; and sand ratio is $0.45-0.50$.

3.2. Design of Concrete Block. HSLW concrete block is the foundation of GSSB. Its weight has been significantly reduced compared with ordinary block. To increase construction efficiency, block specifications were designed. Using GSER with masonry block under similar conditions, we determined the block size to be $500 \mathrm{~mm} \times 250 \mathrm{~mm} \times 200 \mathrm{~mm}$ (length $\times$ width $\times$ height) with two-hole precast. The void ratio of the block is $29.2 \%$, and weight is $34 \mathrm{~kg}$. The structure is shown in Figure 9. 
TABLE 3: Analysis of orthogonal experimental results.

\begin{tabular}{|c|c|c|c|c|c|c|c|c|}
\hline Factors & & $\begin{array}{l}\text { Water- } \\
\text { cement ratio, } \\
\text { A }\end{array}$ & $\begin{array}{l}\text { Volume rate } \\
\text { of sand, B }\end{array}$ & $\begin{array}{l}\text { Content of fly } \\
\text { ash, C }\end{array}$ & $\begin{array}{l}\text { Silica fume } \\
\text { dosages, D }\end{array}$ & $\begin{array}{l}\text { Slump } \\
(\mathrm{cm})\end{array}$ & $\begin{array}{l}\text { Wet density } \\
\qquad\left(\mathrm{kg} / \mathrm{m}^{3}\right)\end{array}$ & $\begin{array}{l}\text { 28-day compressive } \\
\text { strength }(\mathrm{MPa})\end{array}$ \\
\hline & 1 & I $(0.28)$ & I $(0.4)$ & I (10) & I (0) & 26 & 2060 & 58.5 \\
\hline & 2 & I $(0.28)$ & II $(0.45)$ & II (15) & II $(5)$ & 23 & 2060 & 59.5 \\
\hline & 3 & I $(0.28)$ & III $(0.50)$ & III (20) & III (10) & 19 & 2000 & 63.8 \\
\hline & 4 & II $(0.3)$ & I (0.4) & II (15) & III (10) & 14 & 1995 & 54.5 \\
\hline Test number & 5 & II $(0.3)$ & II $(0.45)$ & III (20) & I (0) & 28 & 2122 & 48.5 \\
\hline & 6 & II $(0.3)$ & III $(0.50)$ & I (10) & II (5) & 14 & 2053 & 58.8 \\
\hline & 7 & III (0.32) & I (0.4) & III (20) & II (5) & 25 & 1974 & 60.6 \\
\hline & 8 & III $(0.32)$ & II $(0.45)$ & I (10) & III (10) & 20 & 2032 & 48.8 \\
\hline & 9 & III $(0.32)$ & III $(0.50)$ & II (15) & $\mathrm{I}(0)$ & 28 & 2105 & 50.5 \\
\hline \multirow{4}{*}{ Slump (cm) } & I & 68 & 65 & 60 & 82 & \multirow{4}{*}{\multicolumn{3}{|c|}{$\begin{array}{l}\text { Primary and secondary factors affecting slump: } \\
\text { DACB optimum mix ratio: } A_{3} B_{2} C_{3} D_{1}\end{array}$}} \\
\hline & II & 56 & 71 & 65 & 62 & & & \\
\hline & III & 73 & 61 & 72 & 53 & & & \\
\hline & $R$ & 17 & 10 & 12 & 29 & & & \\
\hline \multirow{4}{*}{ Density $\left(\mathrm{kg} / \mathrm{m}^{3}\right)$} & I & 6120 & 6029 & 6145 & 6287 & \multirow{4}{*}{\multicolumn{3}{|c|}{$\begin{array}{l}\text { Primary and secondary factors affecting density: } \\
\text { DBCA optimum mix ratio: } A_{3} B_{1} C_{3} D_{3}\end{array}$}} \\
\hline & II & 6170 & 6214 & 6160 & 6087 & & & \\
\hline & III & 6111 & 6168 & 6096 & 6028 & & & \\
\hline & $R$ & 59 & 185 & 64 & 259 & & & \\
\hline \multirow{4}{*}{$\begin{array}{l}\text { Compressive } \\
\text { strength }(\mathrm{MPa})\end{array}$} & I & 181.8 & 173.6 & 166.1 & 159.5 & \multirow{4}{*}{\multicolumn{3}{|c|}{$\begin{array}{c}\text { Primary and secondary factors affecting } \\
\text { compressive strength: } A D B C \text { optimum mix } \\
\text { ratio: } A_{1} B_{3} C_{1} D_{2}\end{array}$}} \\
\hline & II & 161.8 & 156.8 & 164.5 & 178.9 & & & \\
\hline & III & 159.9 & 173.1 & 172.9 & 167.1 & & & \\
\hline & $R$ & 21.9 & 16.8 & 8.4 & 19.4 & & & \\
\hline
\end{tabular}

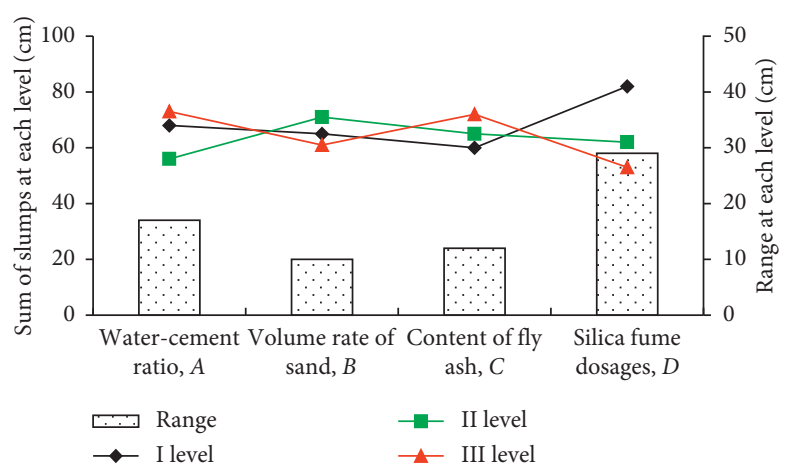

FIgURE 6: Test results of mechanical properties (slump).

TABLE 4: Analysis of variance (slump).

\begin{tabular}{lcccccc}
\hline Factors & Square of deviance & Degree of freedom & Mean square & $F$ & $F$ critical value & Significant \\
\hline Water-cement ratio & 50.889 & 2 & 25.444 & 0.852 & 4.46 & No \\
Volume rate of sand & 16.889 & 2 & 8.444 & 0.283 & 4.46 \\
Content of fly ash & 24.222 & 2 & 12.111 & 0.406 & 4.46 \\
Silica fume dosages & 146.889 & 2 & 73.444 & 2.46 & 4.46 \\
Summation & 238.89 & 8 & & & & No \\
\hline
\end{tabular}

3.2.1. Width Design of Gob-Side Support Body. The width is a key parameter for GSSB stability. It is generally proportional to the support resistance, but the increase of width will also increase the cost and reduce the construction efficiency. At present, there is no unified standard for the width selection of GSSB. Yang et al. [22] summarizes that GSSB width is usually 0.6-0.9 times the mining height. In determining the width, the influence of width on its own stability should be considered to avoid deformation and instability caused by too small width. According to the compressive model shown in Figure 5, the force model is extracted and analyzed separately, as presented in Figure 10.

From Figure 8, when the stress $q_{2}$ on the gob side is less than the strength of the roof and floor strata, the strata will not be cut off:

$$
q_{2} \leq R_{m}=\min \left(R_{r}, R_{f}\right),
$$

where $R_{r}$ is the immediate roof strength, MPa, and $R_{f}$ is the immediate floor strength, MPa.

It can be concluded that 


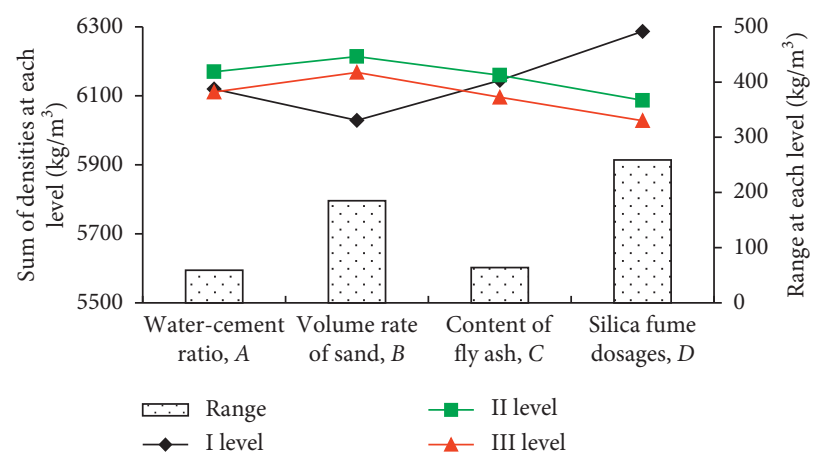

FIgURE 7: Test results of mechanical properties (density).

TABle 5: Analysis of variance (slump).

\begin{tabular}{lcccccc}
\hline Factors & Square of deviance & Degree of freedom & Mean square & $F$ & $F$ critical value & Significant \\
\hline Water-cement ratio & 637.556 & 2 & 336.778 & 0.948 & 6.94 & No \\
Volume rate of sand & 6000.222 & 2 & 3000.111 & 8.448 & 6.94 & Yes \\
Content of fly ash & 746.889 & 2 & 373.445 & 1.052 & 6.94 & No \\
Silica fume dosages & 12355.56 & 2 & 6177.778 & 17.397 & 6.94 \\
Summation & 19776.22 & 8 & & & & \\
\hline
\end{tabular}

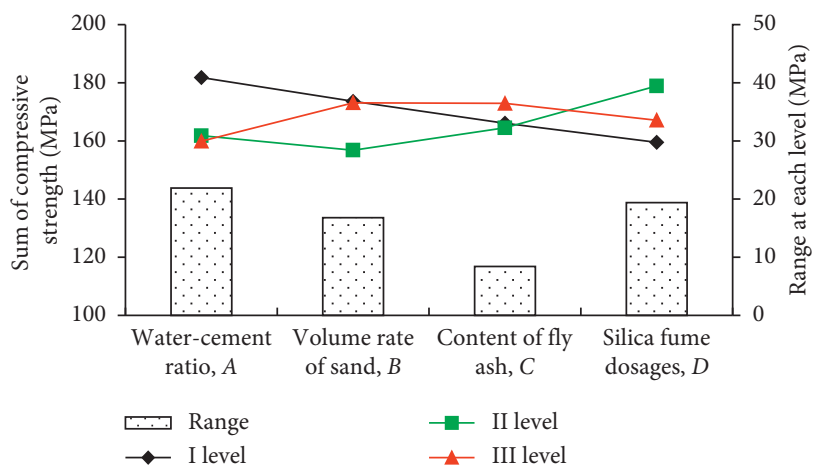

FIGURE 8: Test results of mechanical properties (compressive strength).

TABLE 6: Analysis of variance (slump).

\begin{tabular}{lcccccc}
\hline Factors & Square of deviance & Degree of freedom & Mean square & $F$ & $F$ critical value & Significant \\
\hline Water-cement ratio & 98.136 & 2 & 49.068 & 1.953 & 3.46 & No \\
Volume rate of sand & 60.909 & 2 & 30.455 & 1.212 & 3.46 \\
Content of fly ash & 13.262 & 2 & 6.631 & 0.264 & 3.46 \\
Silica fume dosages & 76.596 & 2 & 37.798 & 1.524 & 3.46 \\
Summation & 248.90 & 8 & & & & No \\
\hline
\end{tabular}

$$
b_{1} \leq \frac{R_{m}\left[\left(h_{a} / E\right)+\left(h_{b} / E_{1}\right)+\left(h_{d} / E_{2}\right)\right] l}{m-(k-1) h_{b}}-x,
$$

where $h_{a}$ is the mining height, $\mathrm{m} ; h_{b}$ is the immediate roof thickness, $\mathrm{m}$; $h_{d}$ is the immediate floor thickness, $\mathrm{m}$; $E, E_{1}$, and $E_{2}$ are the elastic moduli of GSSB, the immediate roof, and the immediate floor, respectively; $k$ is the coefficient of bulk increase of the direct roof; and $x$ is the distance from the main roof basic breaking point to the solid coal wall, $\mathrm{m}$.

Similarly, when the stress $q_{2}$ on the roadway side is less than GSSB strength $R_{G}$, the wall will not be crushed:

$$
q_{2} \leq R_{G}
$$

It can be concluded that

$$
b_{2} \leq \frac{R_{b}\left[\left(h_{a} / E\right)+\left(h_{b} / E_{1}\right)+\left(h_{d} / E_{2}\right)\right] l}{m-(k-1) h_{b}}-(x+a) .
$$

Finally, the width is determined as

$$
b=\min \left(b_{1}, b_{2}\right) \text {. }
$$

The specific parameters were plugged into equations (14) and (16) to calculate the width from the perspective of 


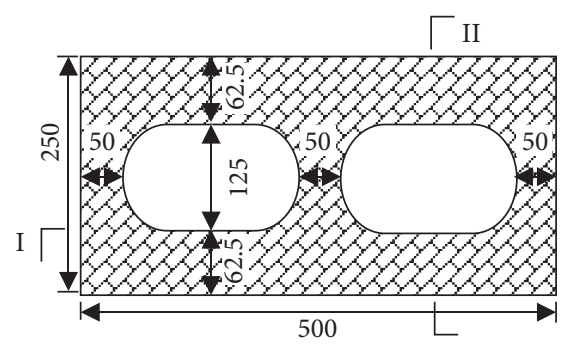

(a)

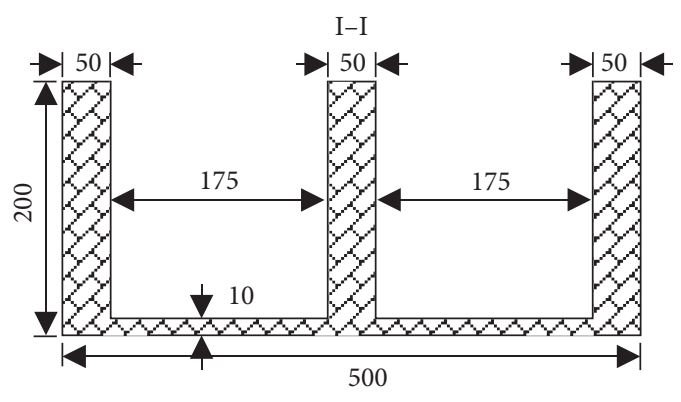

(b)

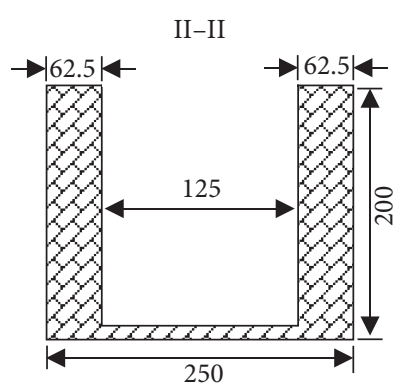

(c)

Figure 9: Block structural design. (a) Top view, (b) I cross section, and (c) II cross section.

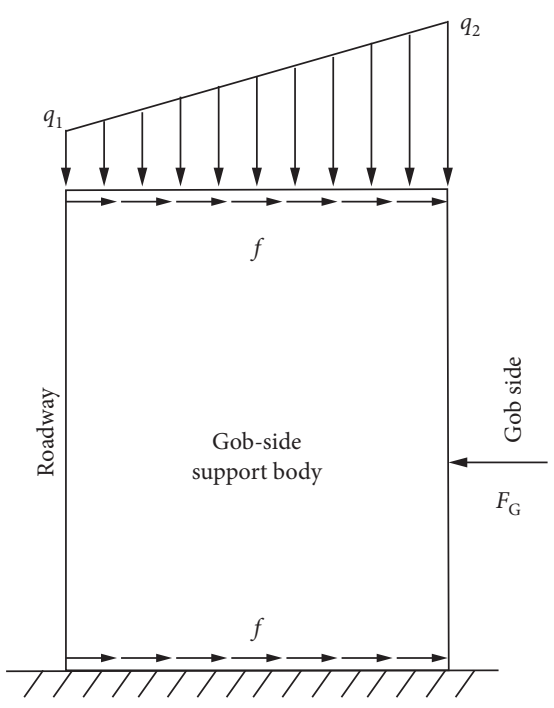

FIGURE 10: Stress analysis of the gob-side support body.

wall failure. From the perspective of stability, the width-height ratio should not be less than 0.5 . Therefore, when the height is $1.4 \mathrm{~m}$, the width should not be lower than $0.7 \mathrm{~m}$. The width of GSSB in NO.-411 working face is calculated as $0.75 \mathrm{~m}$.

3.2.2. Construction Design of Gob-Side Support Body. The irregular arrangement and unscientific combination of blocks will affect the forced state and stability of GSSB. The design adopts the block arrangement mode of "two longitudinal and one horizontal, crisscross, staggered joints." GSSB is generally perpendicular to the roof and floor, and its height is limited by the roof. The voids are filled with wood. The width and the height are $0.75 \mathrm{~m}$ and $1.4 \mathrm{~m}$, respectively, as shown in Figures 11 and 12.

\section{Numerical Simulation}

4.1. Modeling. Figure 13(a) shows the numerical simulation model. The model size is $80 \mathrm{~m} \times 100 \mathrm{~m} \times 80 \mathrm{~m}$ (length $\times$ width $\times$ height), and 150,200 units were divided. Mesh refinement is carried out near the coal seam and the surrounding rock of retained roadway. With the displacement boundary constraint, the $x$ direction velocity of the left and right boundaries is 0 . The $y$ direction velocity of the front and back boundaries is 0 , and the velocities in $x, y$, and $z$ directions at the bottom boundary are 0 . The upper boundary is free boundary, and the self-weight load of the overlying strata is $11.25 \mathrm{MPa}$. The physical mechanics parameters are determined on the basis of in situ original rock parameters. The Mohr-Coulomb model is used as the constitutive model of rock mass. The empty unit model is used to simulate roadway tunneling and working face mining [21]. Figure 13 shows the layout of working face, and Figure 11(c) shows the layout of measuring points. Table 7 shows the mechanical parameters of coal and rock mass.

4.2. Analysis of Different Gob-Side Support Body Widths. This section mainly studies the influence of GSSB with different widths on the deformation characteristics of the surrounding rock. By analyzing stress and deformation, the width can be determined. The following widths were selected for the simulation: $0.5 \mathrm{~m}, 0.75 \mathrm{~m}, 1.0 \mathrm{~m}$, and $1.5 \mathrm{~m}$.

4.2.1. Stress Analysis of Different Widths. Figure 14 illustrates the distribution characteristics of vertical stress of different GSSB widths. The distribution law applies similarly: stress concentration mainly occurs inside GSSB and in the solid coal. When the width increases from $0.5 \mathrm{~m}$ to $0.75 \mathrm{~m}$, the maximum stress in solid coal decreases by $6 \%$, from $31 \mathrm{MPa}$ to $29 \mathrm{MPa}$, and the stress in GSSB significantly increases by $20 \%$, from $5 \mathrm{MPa}$ to $6 \mathrm{MPa}$. When the width increases from $0.75 \mathrm{~m}$ to $1 \mathrm{~m}$, the stress in solid coal decreases by $3 \%$; GSSB, increases by $8 \%$. When the width continues to increase to $1.5 \mathrm{~m}$, stress on both structures still increases but in smaller increments. In general, when width increases, the vertical stress and bearing capacity increase, and pressure on the solid coal is shared, so the stress is reduced. Once the width reaches a certain value, the increase in stress becomes significantly smaller even after continuous width increase.

4.2.2. Deformation Analysis of Roof and Floor. Figure 15 shows the vertical displacement distribution of different widths. When the widths are $0.5 \mathrm{~m}, 0.75 \mathrm{~m}, 1.0 \mathrm{~m}$, and $1.5 \mathrm{~m}$, the maximum vertical displacements at the roof of GSSB are about $340 \mathrm{~mm}, 310 \mathrm{~mm}, 290 \mathrm{~mm}$, and $280 \mathrm{~mm}$, respectively. With the increase in width, the maximum value of vertical 


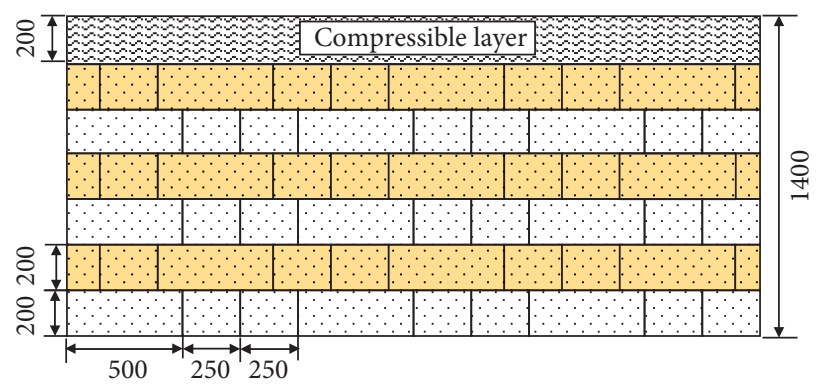

Figure 11: Diagram of the block wall.

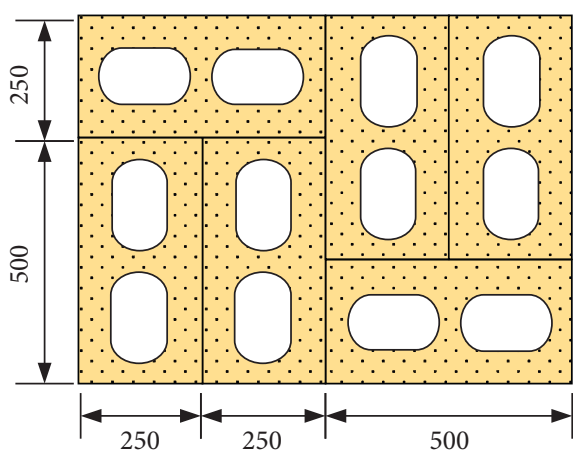

Figure 12: Plane layout of blocks.

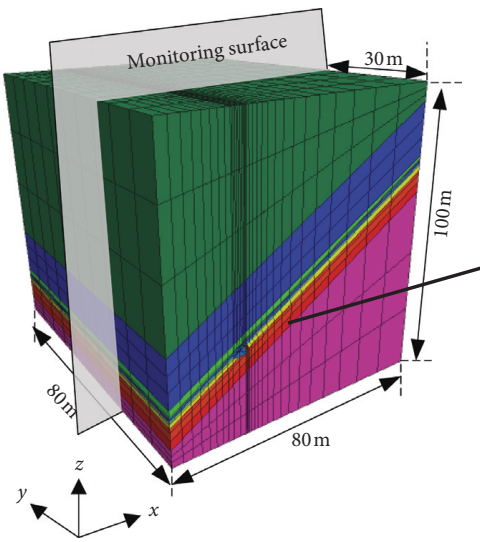

(a)

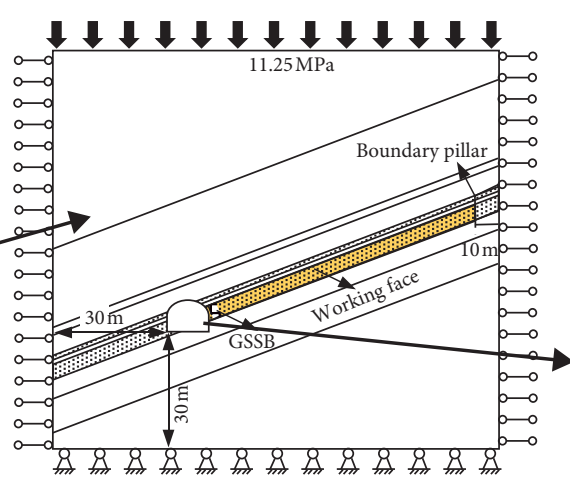

(b)

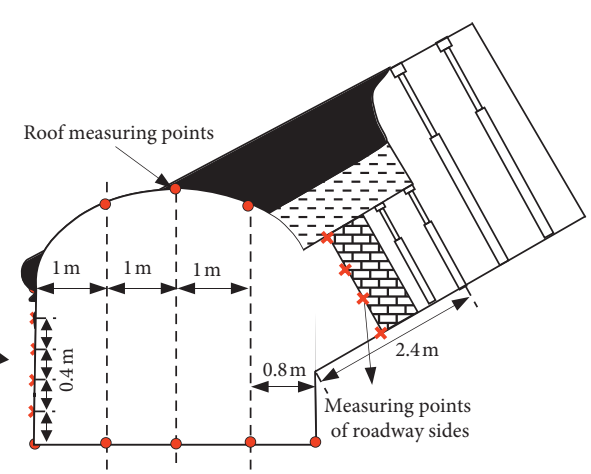

(c)

FIgURE 13: (a) Numerical simulation model, (b) boundary conditions, and (c) layout of measuring points.

Table 7: Mechanics parameters of coal and rock mass.

\begin{tabular}{|c|c|c|c|c|c|}
\hline Lithology & Modulus of elasticity (GPa) & Shear modulus (GPa) & Cohesion (MPa) & Friction angle $\left({ }^{\circ}\right)$ & Density $\left(\mathrm{kg} / \mathrm{m}^{3}\right)$ \\
\hline Siltstone & 11.2 & 7.6 & 3.2 & 32 & 2600 \\
\hline Mudstone & 8 & 4.8 & 2.3 & 30 & 2400 \\
\hline Sandy mudstone & 9.05 & 6.2 & 2.8 & 32 & 2500 \\
\hline Coal & 5 & 2.31 & 1.0 & 28 & 1300 \\
\hline Medium sandstone & 13.1 & 9.02 & 4.4 & 35 & 2600 \\
\hline Goaf & 0.20 & 0.15 & 0.001 & 5 & 1900 \\
\hline C40 concrete & 18 & 11.61 & 3.1 & 35 & 2400 \\
\hline C50 concrete & 18.6 & 11.96 & 3.6 & 37 & 2450 \\
\hline C60 concrete & 19.7 & 12.78 & 4.1 & 40 & 2600 \\
\hline LC50 concrete & 16.4 & 10.9 & 3.8 & 40 & 2042 \\
\hline
\end{tabular}




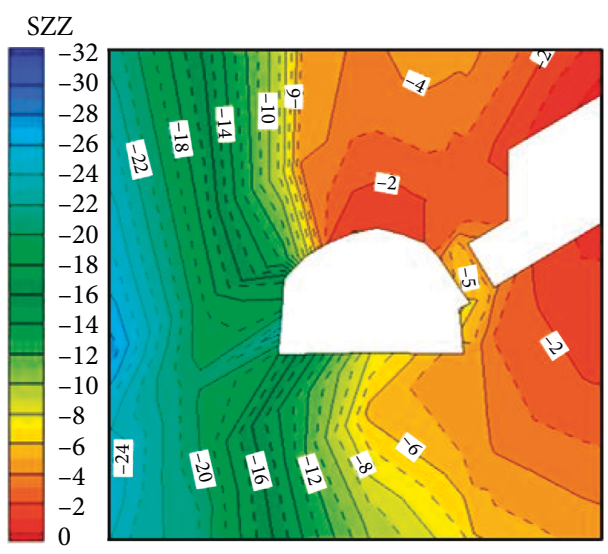

(a)

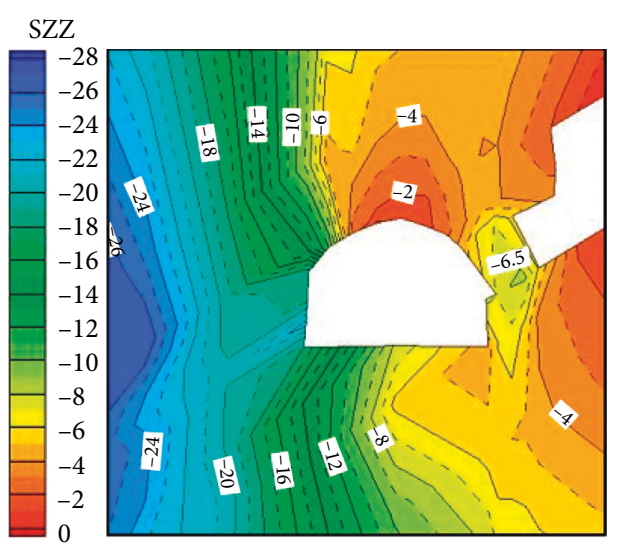

(c)

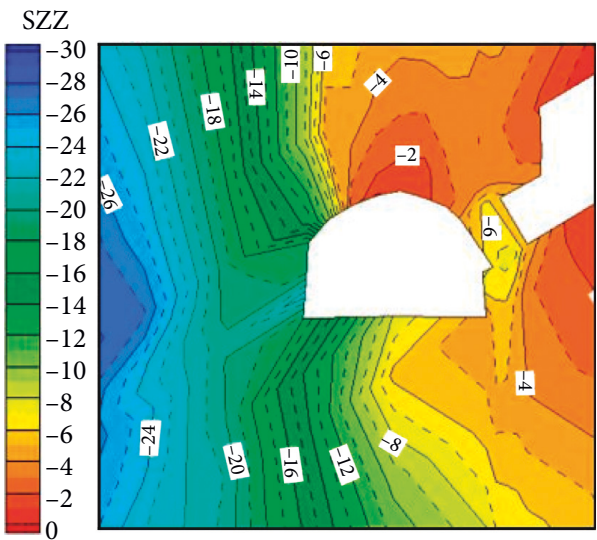

(b)

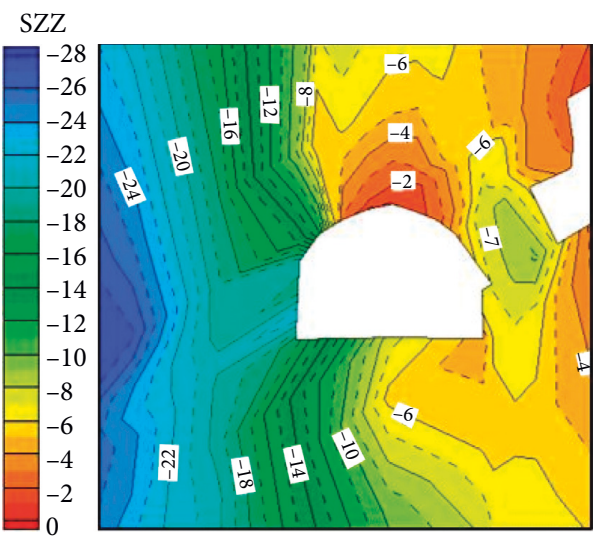

(d)

Figure 14: Vertical stress distributions of different GSSB widths: (a) $0.5 \mathrm{~m}$, (b) $0.75 \mathrm{~m}$, (c) $1.0 \mathrm{~m}$, and (d) $1.5 \mathrm{~m}$.

displacement gradually decreases, and the change of deformation tends to be stable. Therefore, support at the roof of GSSB should be strengthened during the roadway retaining construction.

Figures 16 and 17 show the displacement curves of the roof and floor. The arrangement of measuring points is shown in Figure 13(c). Deformation gradually decreases with the increase in width. As width increases from $0.5 \mathrm{~m}$ to $0.75 \mathrm{~m}$, the subsidence decreases from $32 \mathrm{~mm}$ to $39 \mathrm{~mm}$, averaging $35.5 \mathrm{~mm}$; the floor heave reduces from $28 \mathrm{~mm}$ to $32 \mathrm{~mm}$, averaging $30 \mathrm{~mm}$. The displacement decreases the most in this stage. When the width increases from $0.75 \mathrm{~m}$ to $1 \mathrm{~m}-1.5 \mathrm{~m}$, deformation continues to decrease but in smaller increments.

4.2.3. Deformation Analysis of Roadway Sides. Figure 18 shows the horizontal displacement contour maps of different GSSB widths; Figures 19 and 20 present the displacement curves of the solid coal wall and GSSB, respectively. With the increase in width, the deformation of the two sides decreases gradually. The deformation of the coal side is larger than that of the other side. The integrated coal side displacement increases from the floor to roof, whereas the deformation of GSSB side is large in the middle and small on both sides. When the width increases from $0.5 \mathrm{~m}$ to $0.75 \mathrm{~m}$, the displacements of the coal side and the GSSB side both decrease to $20 \mathrm{~mm}$ and $19.5 \mathrm{~mm}$, respectively. When the width increases from $0.75 \mathrm{~m}$ to $1 \mathrm{~m}$, the deformation of both sides continues to decrease but in smaller increments.

From the above analysis, there is a reasonable value for the width, calculated to be $0.75 \mathrm{~m}$. When the width is less than the value, the deformation of the roof, floor, and two sides of roadway is large; when the width is close to the value, the deformation of the roadway is significantly reduced. When it is larger than this value, the deformation does not decrease significantly, and it gradually stabilizes. In addition, the standard width not only controls the deformation and ensures the success of GSER, but it also effectively reduces the construction duration and cost, achieving high production and high efficiency of the working face.

4.3. Analysis of Different Strengths. To analyze the influence of different material strengths on the deformation of the surrounding rock, the following concrete materials were selected: C40, C50, C60, and LC50. They were subjected to numerical simulation analysis using $0.75 \mathrm{~m}$ as GSSB width.

4.3.1. Stress Analysis of Different Materials. Figure 21 shows the vertical stress distributions of different concrete materials. The stress concentration mainly occurs inside the GSSB 


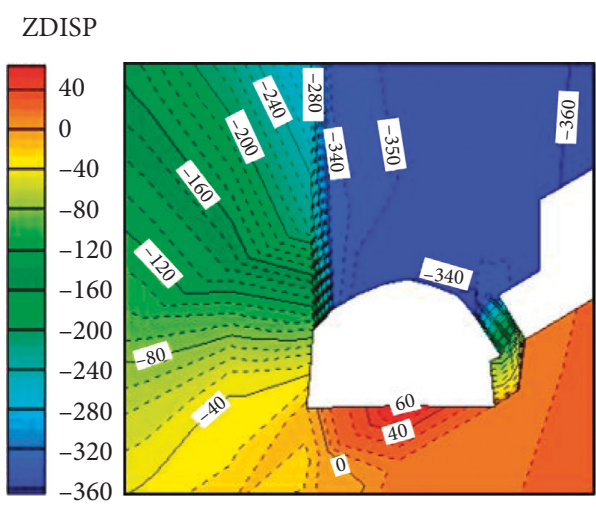

(a)

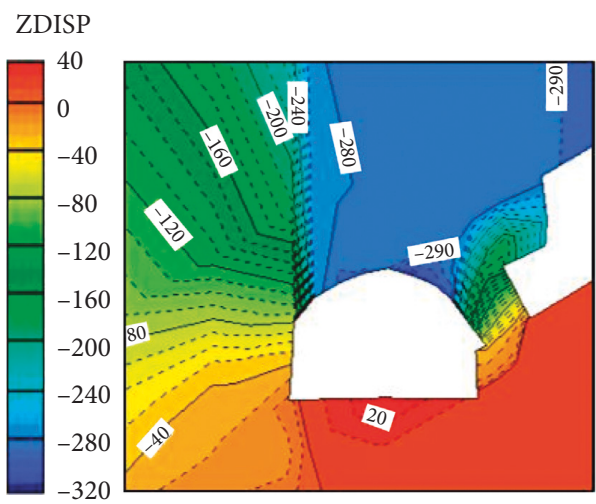

(c)

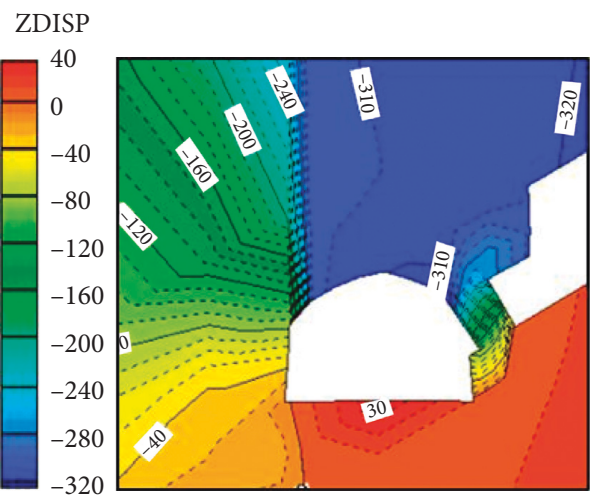

(b)

ZDISP
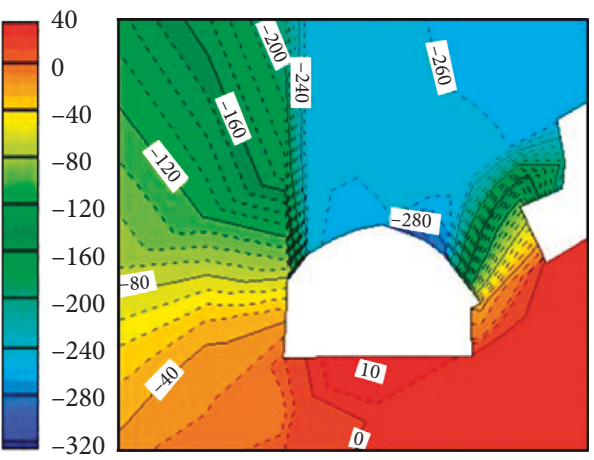

(d)

FIGURE 15: Vertical stress distributions of different GSSB widths: (a) $0.5 \mathrm{~m}$, (b) $0.75 \mathrm{~m}$, (c) $1.0 \mathrm{~m}$, and (d) $1.5 \mathrm{~m}$.

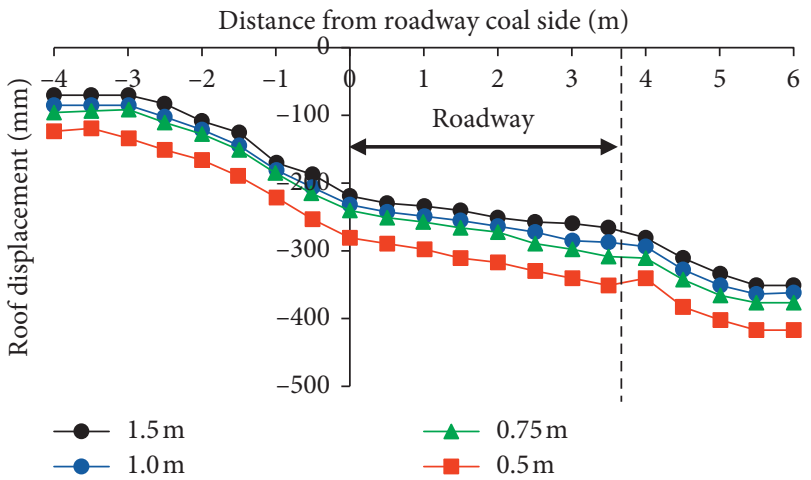

Figure 16: Displacement curve of the roof.

and the solid coal, and the stress peak changes with the change in concrete material. When $\mathrm{C} 40, \mathrm{C} 50$, and $\mathrm{C} 60$ are used, the maximum stress in integrated coal is $31 \mathrm{MPa}$, $30 \mathrm{MPa}$, and $29 \mathrm{MPa}$, whereas maximum stress in GSSB is $4 \mathrm{MPa}$, 5.5 MPa, and $7 \mathrm{MPa}$, respectively. With the increase in strength, the stress inside GSSB and the bearing capacity both increase. The pressure generated by overlying strata and shared by GSSB increases gradually. When the material strength is LC50, the stress value is basically the same as C60. LC50 concrete GSSB has stronger bearing capacity, receiving more pressure from overlying strata than other materials.

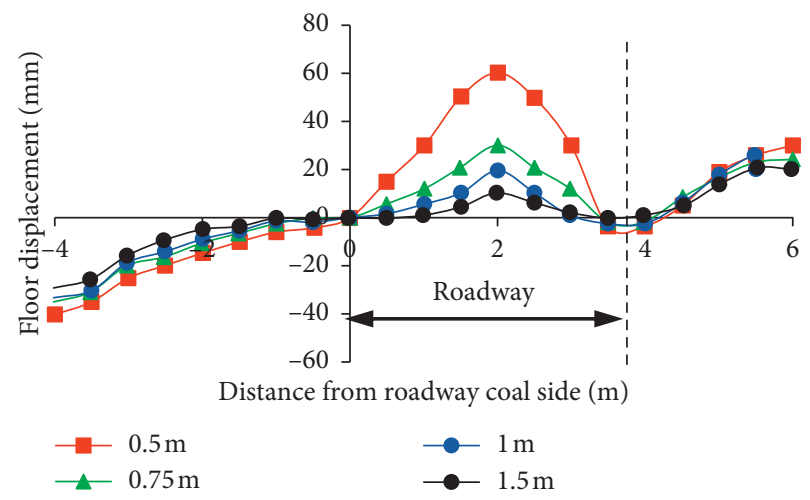

FIGURE 17: Deformation curve of the floor.

4.3.2. Deformation Analysis of Roof and Floor. Figure 22 displays the vertical displacement nephograms of different concrete materials; Figures 23 and 24 show the displacement curves of roof and floor, respectively. The arrangement of measuring points is shown in Figure 11(c). The roof subsidence increases gradually from the solid coal side to the GSSB side, and there is a concentrated area above the GSSB. When the materials are C40, C50, C60, and LC50, the maximum displacement is $360 \mathrm{~mm}, 320 \mathrm{~mm}, 310 \mathrm{~mm}$, and $300 \mathrm{~mm}$, respectively. With the increase in strength, the increments become smaller and stabilize. When the supporting material changes from $\mathrm{C} 40$ to $\mathrm{C} 50$, the subsidence of 


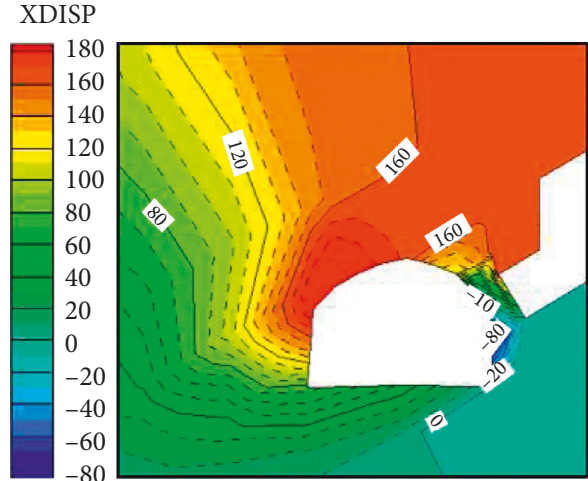

(a)

\section{XDISP}

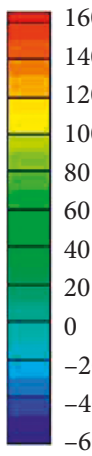

(c)

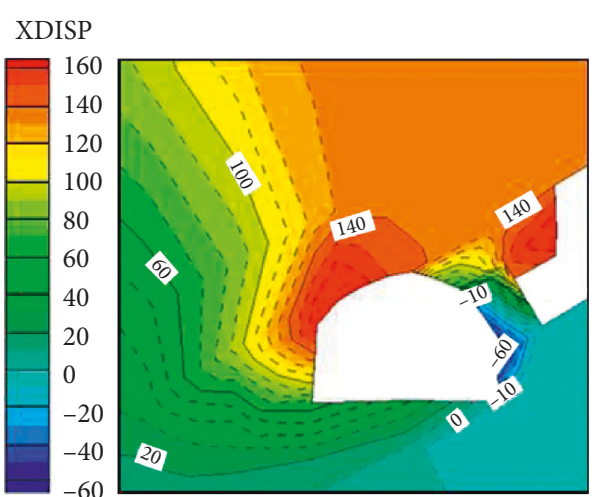

(b)

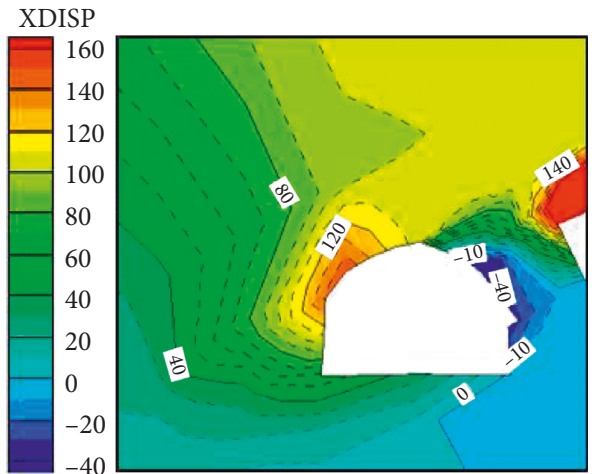

(d)

Figure 18: Horizontal displacement distributions of different GSSB widths: (a) $0.5 \mathrm{~m}$,(b) $0.75 \mathrm{~m}$, (c) $1.0 \mathrm{~m}$, and (d) $1.5 \mathrm{~m}$.

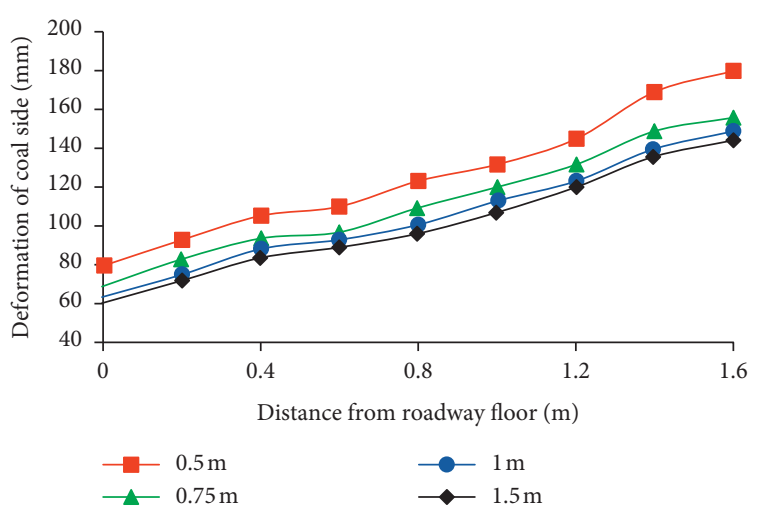

Figure 19: Displacement of roadway coal side.

the roadway roof decreases to $35 \mathrm{~mm}$ on average, and the floor heave decreases to $10 \mathrm{~mm}$ on average. When the supporting material changes from C50 to C60 and LC50 is with similar average displacement values, the subsidence of the roadway roof decreases to $19.8 \mathrm{~mm}$, and the floor heave decreases to $10 \mathrm{~mm}$ on average.

4.3.3. Deformation Analysis of Road Sides. Figure 25 shows the contour maps of horizontal displacement of different concrete materials. Figures 26 and 27 present the displacement curves of integrated coal side and GSSB side,

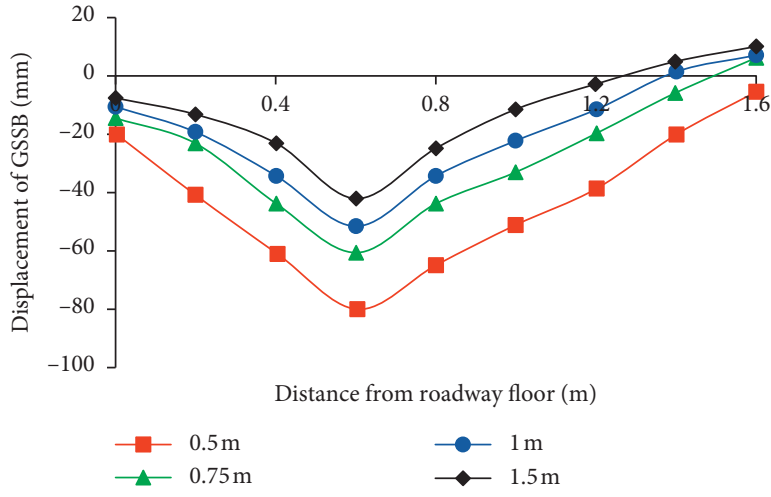

Figure 20: Displacement of GSSB.

respectively. The horizontal displacement decreases with the increase in material strength. The overall displacement distribution is asymmetric, and there are displacement concentration zones on the integrated coal side roof and the GSSB side. The change law of horizontal displacement is consistent with the vertical displacement in the roof and floor. With the increase in strength, deformation decreases and tends to be stable.

In conclusion, when the width is determined, the material strength has a standard value. When the strength is less than this value, the deformation of roadway is large, and the effect of retained roadway is poor. When the strength is equal to this 


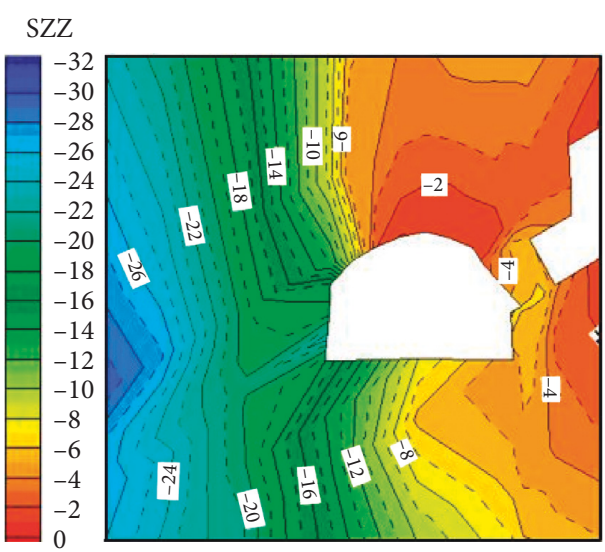

(a)

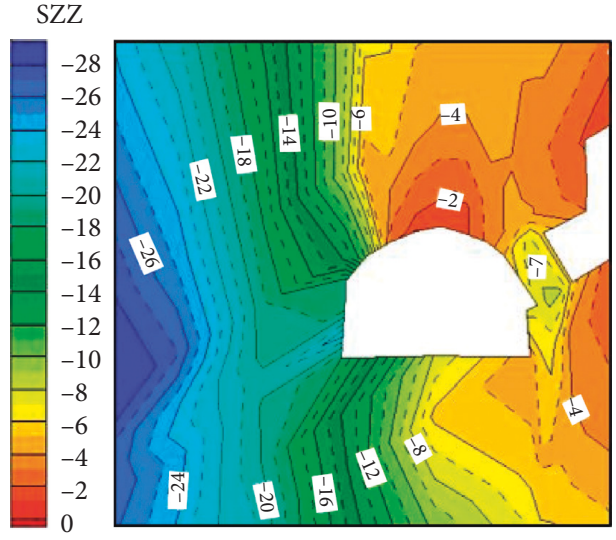

(c)

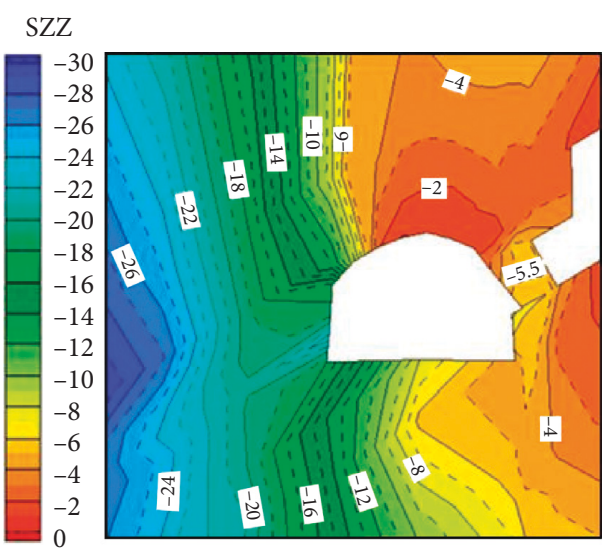

(b)

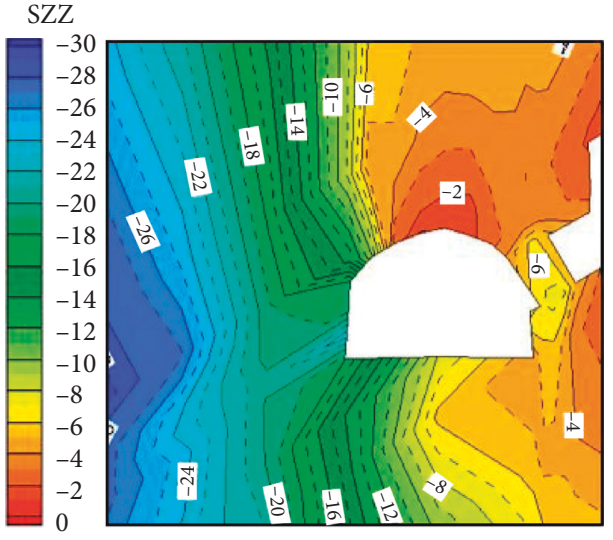

(d)

FIgURE 21: Vertical stress distributions of different concrete materials: (a) C40, (b) C50, (c) C60, and (d) LC50.

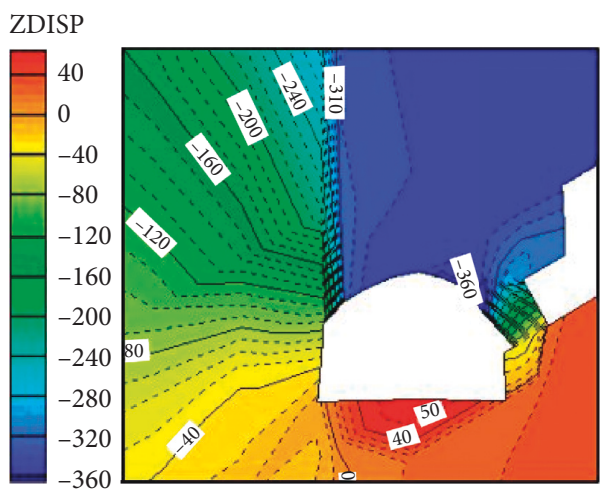

(a)

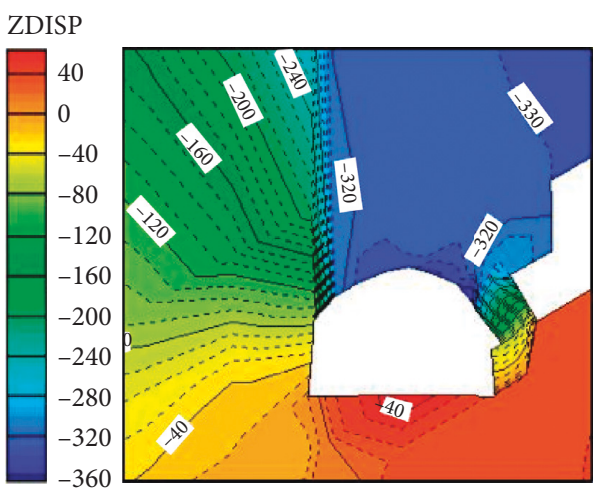

(b)

Figure 22: Continued. 


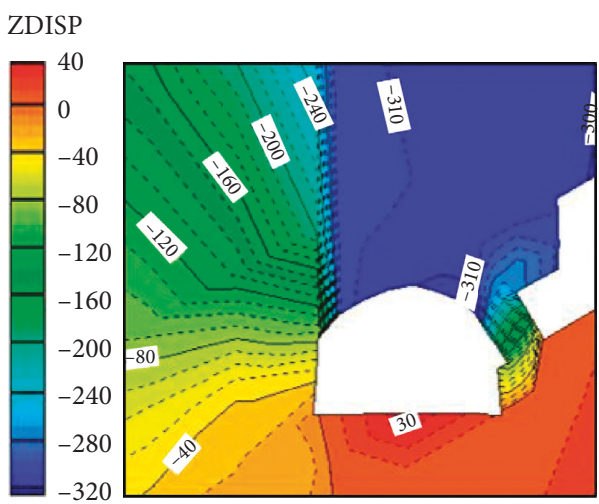

(c)
ZDISP

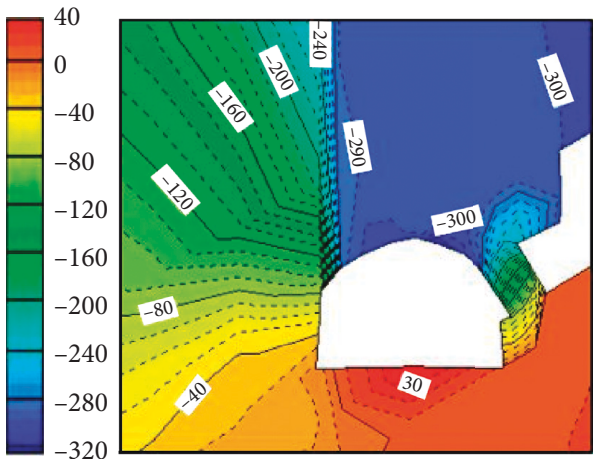

(d)

Figure 22: Vertical displacement nephograms of different concrete materials: (a) C40, (b) C50, (c) C60, and (d) LC50.

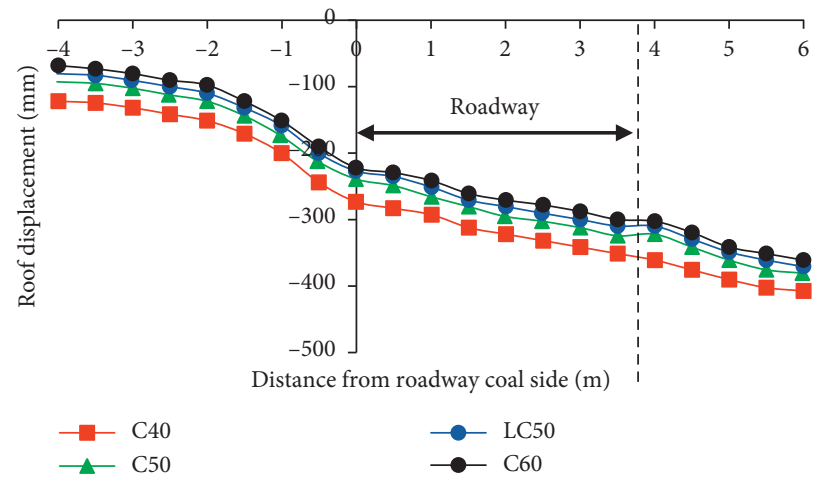

FIGURE 23: Displacement curve of the roof.

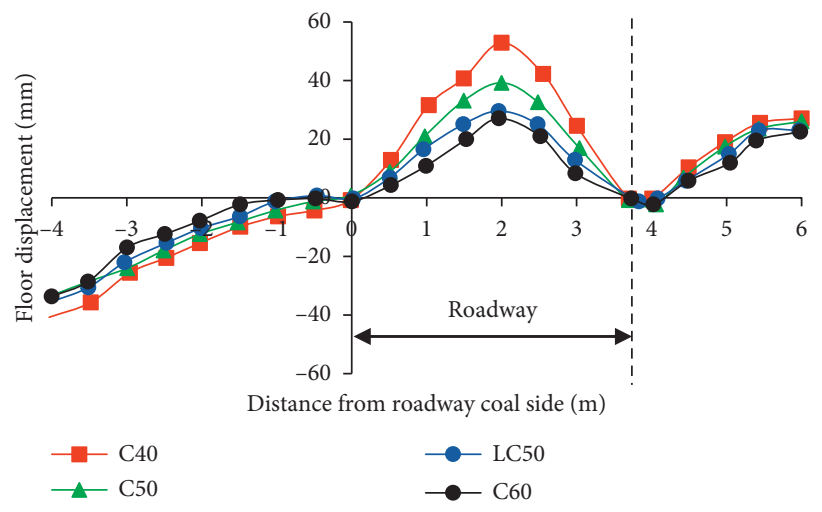

Figure 24: Deformation curve of the floor.

value, the deformation decreases expectedly. When the strength is greater than this value, the deformation does not decrease significantly. Considering the supporting effect, economic cost, construction cost, and other aspects, LC50 concrete selection is the most appropriate material for our purposes.

\section{Field Monitoring}

5.1. Station Layout. To study the effect of GSER, the following steps were done: monitoring of the retained roadway deformation, analysis of the deformation characteristics of surrounding rock, and evaluation of the supporting effect of retained roadway, which provides a basis for further optimizing roadway support scheme. Four stations are set up in the retained roadway, with a $15 \mathrm{~m}$ spacing. Three monitoring points are set in each station and numbered consecutively, as shown in Figure 28. This mainly monitors the convergence between roof and floor. All stations are monitored simultaneously. Monitoring station I started the observation from $15 \mathrm{~m}$ in front of the working face until $165 \mathrm{~m}$ behind the working face. 
XDISP

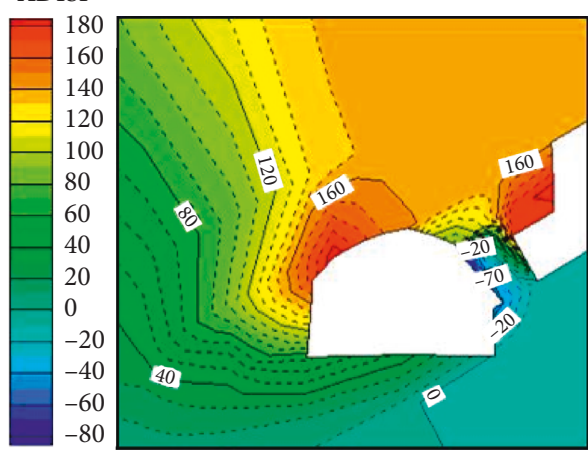

(a)

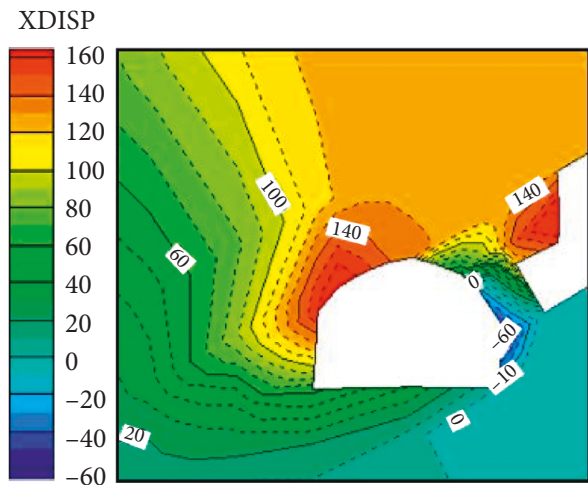

(c)
XDISP

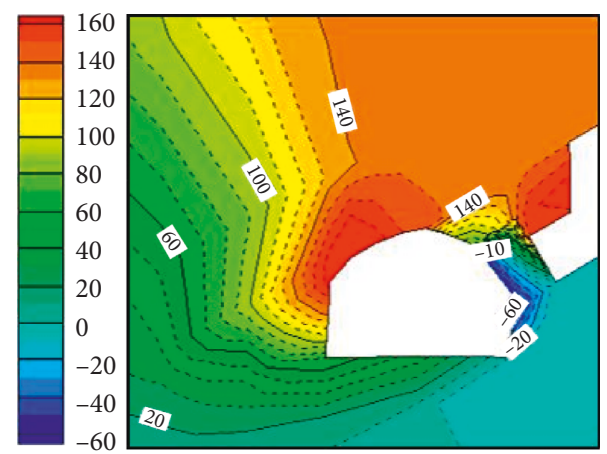

(b)
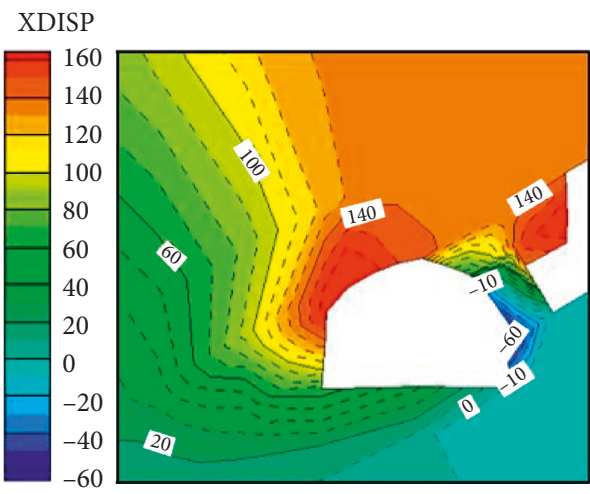

(d)

FIgURE 25: Horizontal displacements of different concrete materials: (a) C40, (b) C50, (c) C60, and (d) LC50.

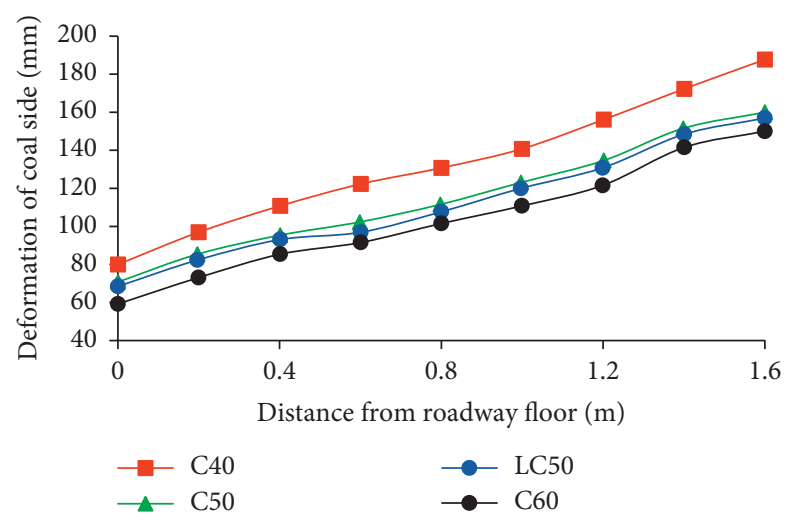

Figure 26: Displacement of the roadway coal side.

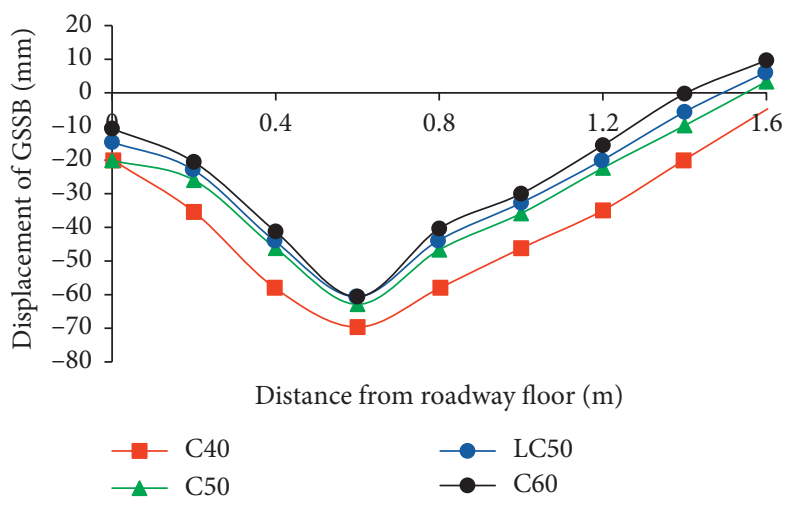

FIGURE 27: Displacement of the supporting body side. 


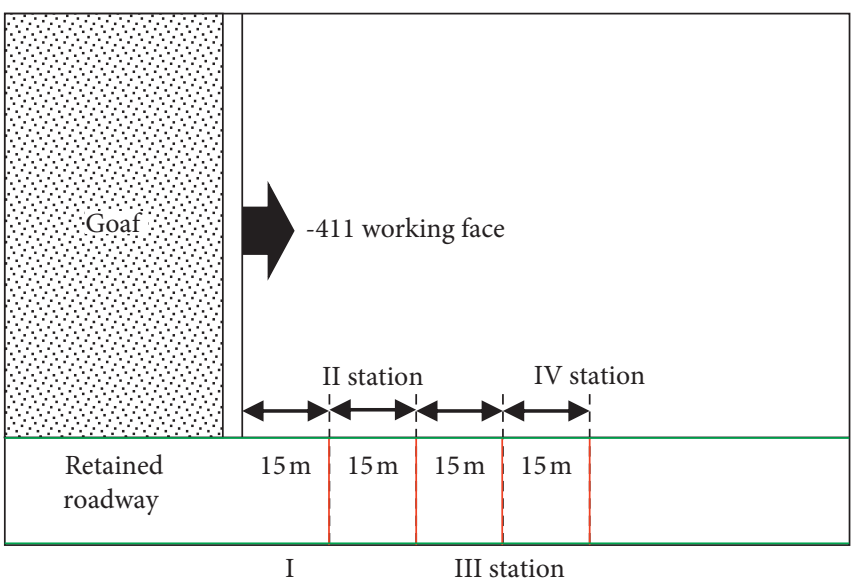

(a)

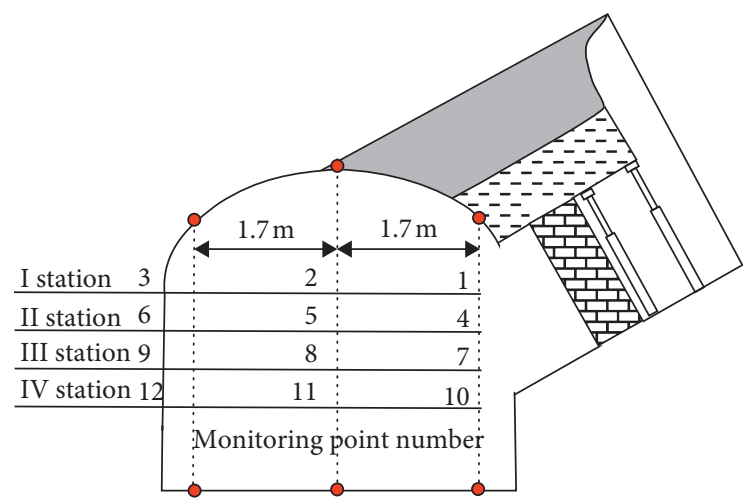

(b)

FIGURE 28: (a) Station layout plan. (b) Layout of measuring points.

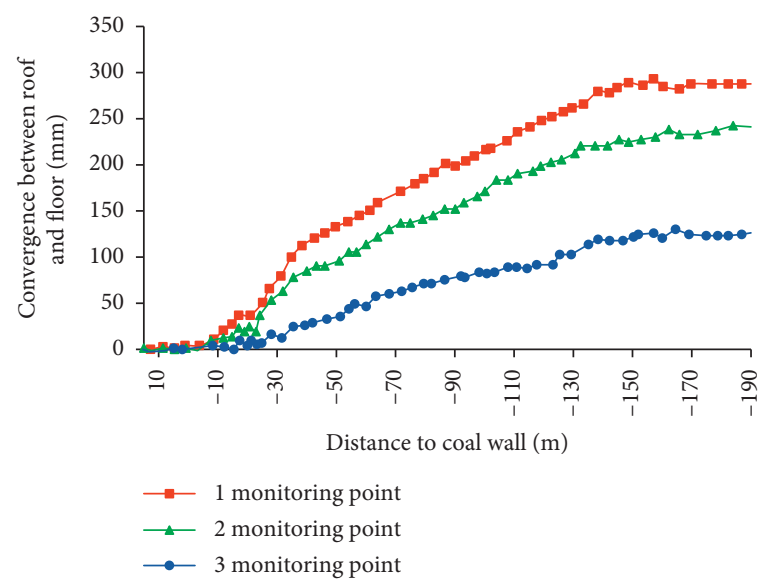

(a)

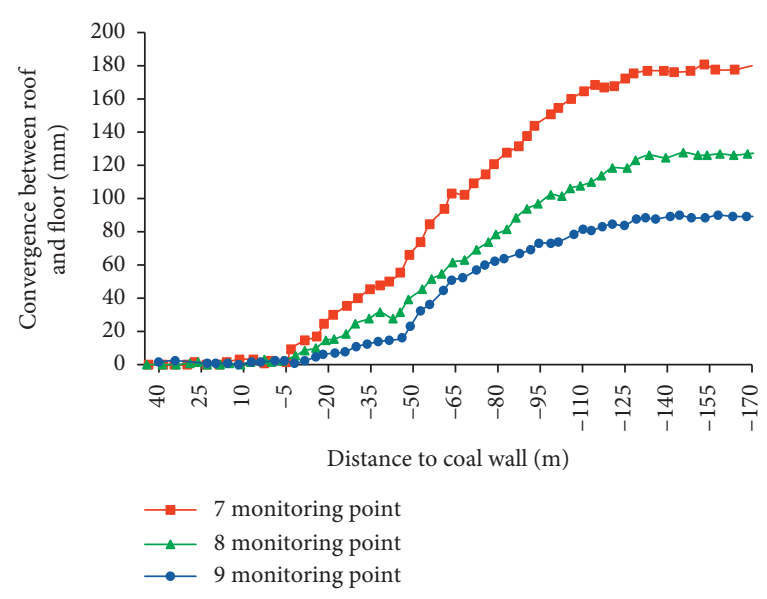

(c)

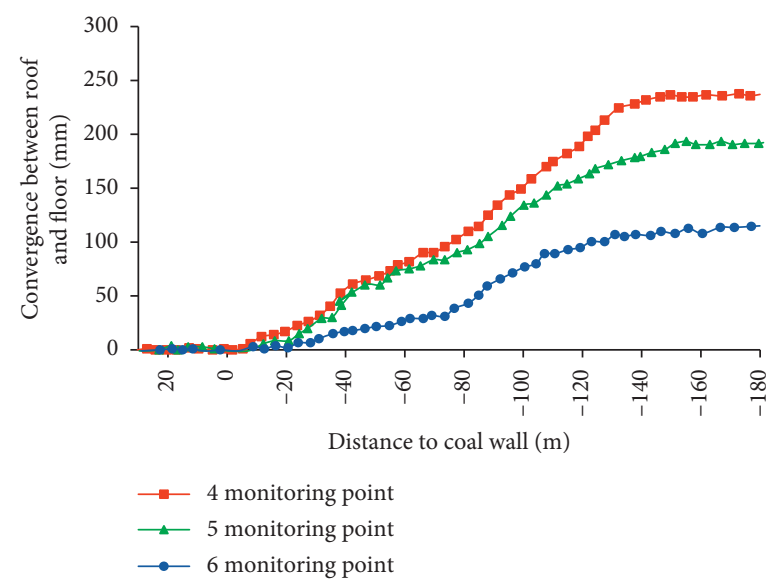

(b)

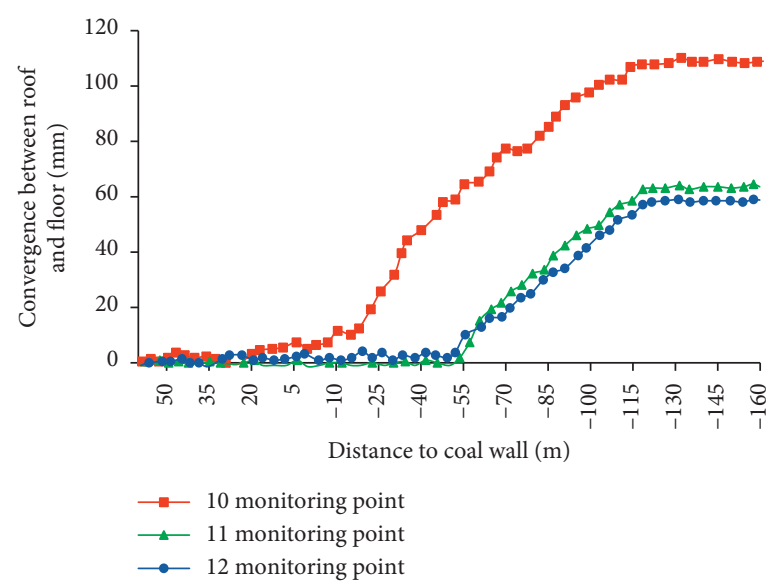

(d)

FIGURE 29: Convergence between the roadway roof and floor as observed from four monitoring stations. (a) I station. (b) II station. (c) III station. (d) IV station.

5.2. Result. Figure 29 shows the displacement curves of roof and floor at four stations. The convergence between roof and floor near the GSSB side is the largest, whereas the entity coal side is the smallest, indicating that the GSSB side roof is the most active. The displacement of the roof of the solid coal side is small; the subsidence space is limited; and the pressure is 


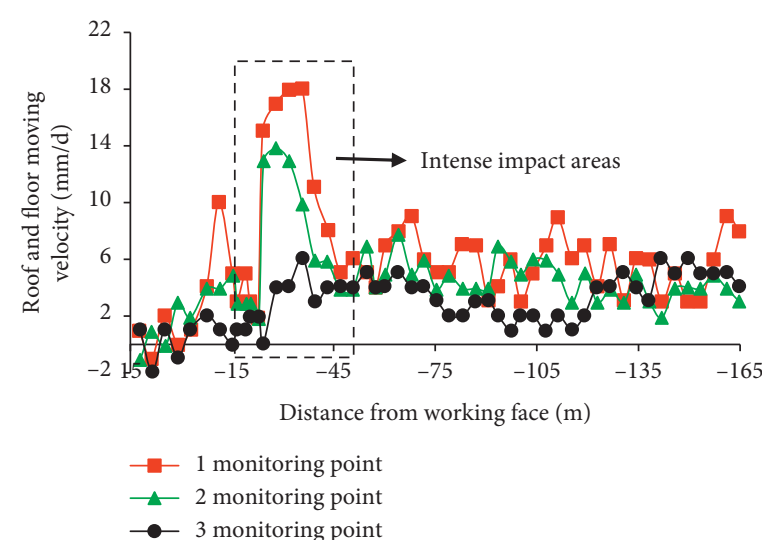

(a)

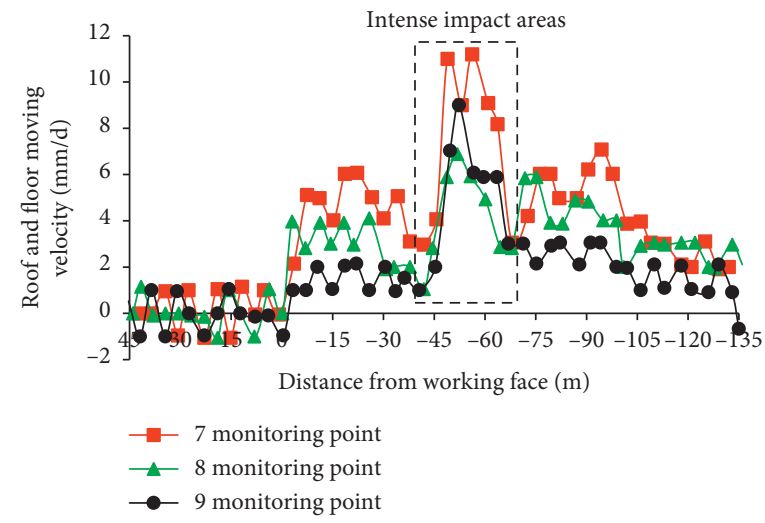

(c)

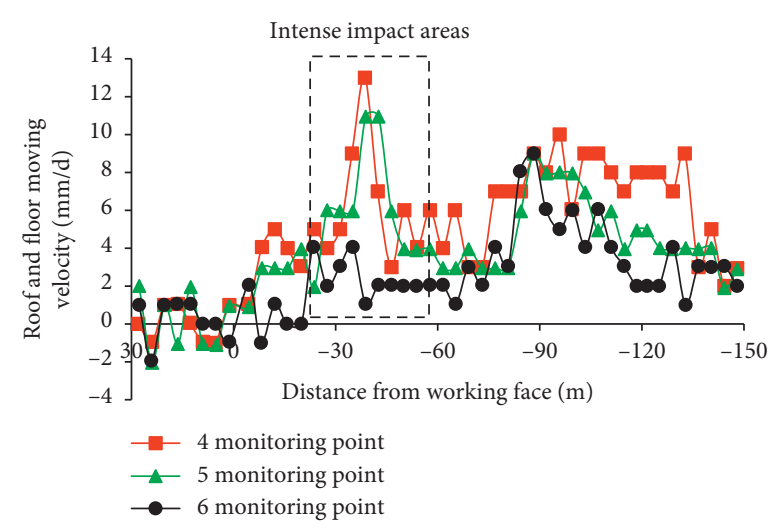

(b)

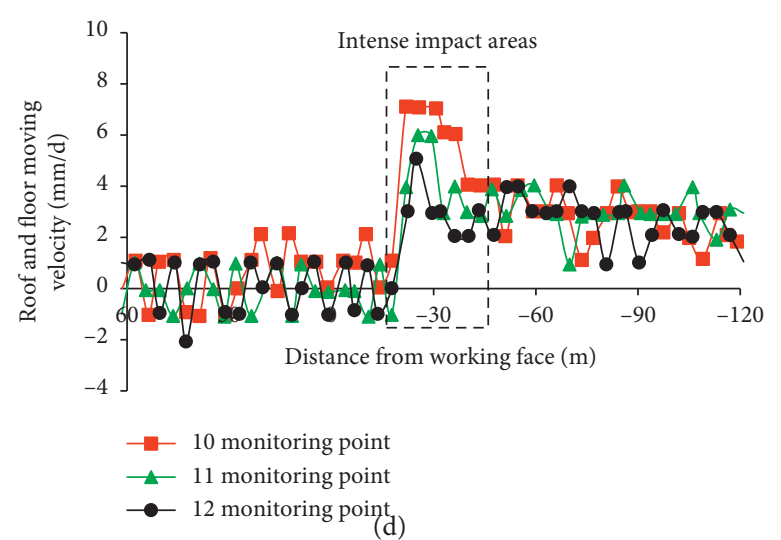

FIgURE 30: Roof and floor moving velocities of four monitoring stations. (a) I station. (b) II station. (c) III station. (d) IV station.

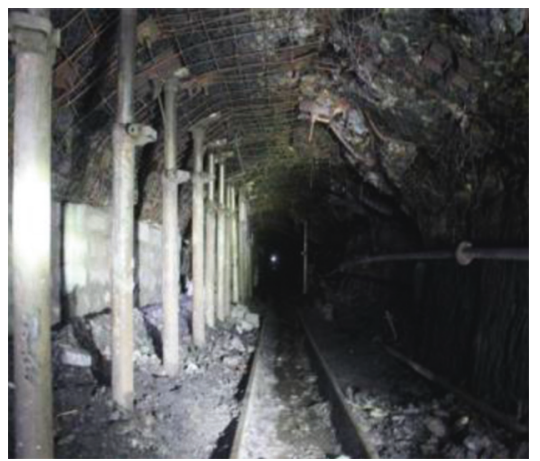

(a)

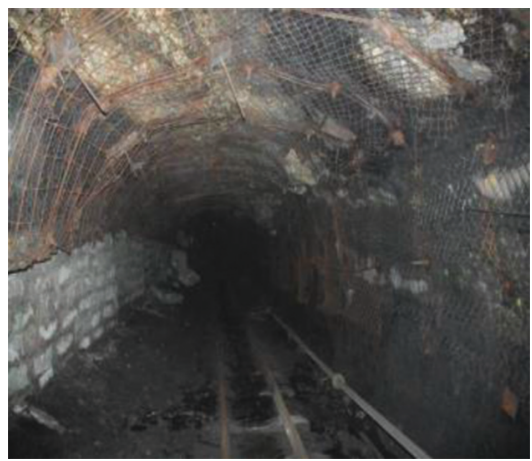

(b)

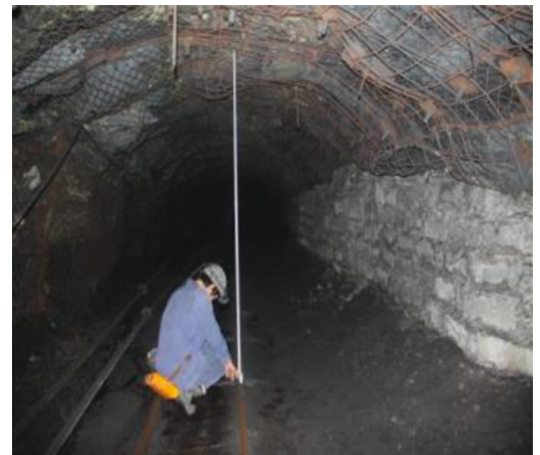

(c)

Figure 31: The effect of gob-side entry retaining: (a) $30 \mathrm{~m}$ from working face, (b) $100 \mathrm{~m}$ from working face, and (c) $180 \mathrm{~m}$ from working face.

not completely released. To avoid the occurrence of large area rib spalling, it is necessary to carry out reasonable support design for the entity coal side. From the monitoring data, the convergence between roof and floor is all below $380 \mathrm{~mm}$ and can be effectively controlled through corresponding support measures at different stages. The roadway deformation is also small, and the effect of GSER is good.

Figure 30 shows the velocity of convergence between roof and floor of the monitoring points. The moving velocity varies greatly from $5 \mathrm{~m}$ to $50 \mathrm{~m}$ from the working face. It indicates that with the advance of the working face, the movement of roadway roof and floor is relatively intense within this range. To avoid the deformation and destruction of retained roadway caused by the violent activities of the roof and floor, appropriate supporting measures should be taken at this distance.

From field observation, the deformation of the retained roadway with HSLW concrete blocks changes as the working 
surface advances. However, the overall deformation of the roadway surrounding rock is not large, and there is no considerably large damage observed. The stability of the retained roadway can also be maintained during this period of intense roof activity; hence, the deformation meets the safety requirements. It is proved that the support design of GSER with HSLW blocks is feasible. Figure 31 shows the effect of GSER.

\section{Conclusions}

(1) Based on Jingang Coal Mine NO.-411 inclined coal seam GSER, the application of HSLW concrete masonry is studied. Firstly, the force model of GSSB is established, and the limit angle of its stability is obtained. Secondly, the mechanical model of roadway-side supporting resistance is established, and the calculation for support resistance is deduced using the strip segmentation method. Finally, the compression model of the inclined GSSB is established, and the theoretical compression deformation value is calculated, which provides a theoretical basis for the design of GSSB.

(2) From the orthogonal experimental method, the performance LC50 HSLW concrete was tested, and the optimum mix ratio was investigated. The final mix ratio is determined to be water-cement ratio, 0.30 ; silica fume dosage, less than 10\%; fly ash dosage, between 10 and 20\%; and sand ratio, 0.45-0.50. 800grade ceramsite was selected as the lightweight aggregate. The design of the concrete supporting body was performed, and the size and arrangement of concrete blocks were determined. Finally, the width of GSSB was calculated to be $0.75 \mathrm{~m}$.

(3) The feasibility of the calculated width and chosen concrete material of GSSB were studied in a numerical simulation. Four width models of $0.5 \mathrm{~m}$, $0.75 \mathrm{~m}, 1.0 \mathrm{~m}$, and $1.5 \mathrm{~m}$ were established by FLAC3D numerical simulation software. The influence of different widths on surrounding rock deformation was investigated. The standard width of GSSB was determined from the stress analysis of the surrounding rock and the deformation of roof, floor, and two sides. Four models of concrete material with different strengths were used as samples: C40, C50, C60, and LC50. Their influence on the surrounding rock deformation is analyzed, and the standard strength value of supporting material is determined.

(4) The design scheme was applied in the field and monitored. Field monitoring results show that $5 \mathrm{~m}-45 \mathrm{~m}$ in front of the working face is affected by advanced stress, the roof and floor moving velocities are larger, and other deformation is relatively stable. The convergence between roof and floor is below $380 \mathrm{~mm}$, and the deformation is effectively controlled without major damage. It shows that the design of GSER with HSLW concrete block is feasible.

\section{Data Availability}

The data used to support the findings of this study are available from the corresponding author upon request.

\section{Conflicts of Interest}

The authors declare that they have no conflicts of interest.

\section{References}

[1] M. C. He, H. P. Xie, S. P. Peng, and Y. D. Jiang, "Study on rock mass mechanics in deep mining," Chinese Journal of Rock Mechanics and Engineering, vol. 16, pp. 2803-2813, 2005.

[2] X. Z. Hua, "Study on gob-side entry retaining technique with roadside packing in longwall top-coal caving technology," Journal of Coal Science Engineering, vol. 10, no. 1, pp. 9-12, 2004.

[3] A. Azadeh, M. Osanloo, and M. Ataei, "A new approach to mining method selection based on modifying the Nicholas technique," Applied Soft Computing, vol. 10, no. 4, pp. 1040-1061, 2010.

[4] H. Basarir, Y. Sun, and G. Li, "Gateway stability analysis by global-local modeling approach," International Journal of Rock Mechanics and Mining Sciences, vol. 113, pp. 31-40, 2019.

[5] R. G. David and J. Rafael, "A probabilistic extension to the empirical ALPS and ARMPS systems for coal pillar design," International Journal of Rock Mechanics and Mining Sciences, vol. 52, pp. 181-198, 2012.

[6] L. S. Jiang, P. Wang, P. Q. Zheng, H. J. Luan, and C. Zhang, "Influence of different advancing directions on mining effect caused by a fault," Advances in Civil Engineering, vol. 2019, Article ID 7306850, 10 pages, 2019.

[7] X. S. Liu, J. G. Ning, Y. L. Tan, Q. Xu, and D. Y. Fan, "Coordinated supporting method of gob-side entry retaining in coal mines and a case study with hard roof," Geomechanics and Engineering, vol. 15, no. 6, pp. 1173-1182, 2018.

[8] C. L. Han, N. Zhang, G. C. Li, B. Y. Li, and H. Wu, "Stability analysis of composite bearing structure near goaf retaining roadway with large mining height," Chinese Journal of Geotechnical Engineering, vol. 36, no. 5, pp. 969-976, 2014.

[9] P. Wang, L. S. Jiang, P. Q. Zheng, G. P. Qin, and C. Zhang, "Inducing mode analysis of rock burst in fault-affected zone with a hard-thick stratum occurrence," Environmental Earth Science, vol. 78, no. 15, p. 467, 2019.

[10] Z. Z. Zhang, W. J. Wang, S. Q. Li, J. B. Bai, S. P. Hao, and $\mathrm{X}$. Y. Yu, "An innovative approach for gob-side entry retaining with thick and hard roof: a case study," Technical Gazette, vol. 25, no. 4, pp. 1028-1036, 2018.

[11] A. M. Suchowerska, R. S. Merifield, and J. P. Carter, "Vertical stress changes in multi-seam mining under supercritical longwall panels," International Journal of Rock Mechanics and Mining Sciences, vol. 61, pp. 306-320, 2013.

[12] Q. Wang, Q. Qin, B. Jiang, H. C. Yu, R. Pan, and S. C. Li, "Study and engineering application on the bolt-grouting reinforcement effect in underground engineering with fractured surrounding rock," Tunnelling and Underground Space Technology, vol. 84, pp. 237-247, 2019.

[13] Q. Wang, M. He, J. Yang, H. Gao, B. Jiang, and H. Yu, "Study of a no-pillar mining technique with automatically formed gob-side entry retaining for longwall mining in coal mines," International Journal of Rock Mechanics and Mining Sciences, vol. 110, pp. 1-8, 2018. 
[14] Y. L. Tan, W. M. Li, S. J. Miao, P. Wei, T. B. Zhao, and Q. Li, "Numerical simulation on the stress distribution of thin seam containing iron-sulfide-cores," Applied Mechanics and Materials, vol. 316-317, pp. 799-802, 2013.

[15] J. Wang, Y. F. Gao, X. S. He, W. P. Huang, Q. P. Gao, and S. W. Feng, "Analysis of roadway side support parameters along goaf retaining and study of concrete filled steel tubular pier and column support technology," Journal of Mining and Safety Engineering, vol. 32, no. 6, pp. 943-949, 2015.

[16] P. Wang, L. S. Jiang, J. Q. Jiang, P. Q. Zheng, and W. Li, “Strata behaviors and rock-burst-inducing mechanism under the coupling effect of a hard thick stratum and a normal fault," International Journal of Geomechanics, vol. 18, no. 2, pp. 1-14, 2018.

[17] J. Ning, J. Wang, X. Liu, K. Qian, and B. Sun, "Soft-strong supporting mechanism of gob-side entry retaining in deep coal seams threatened by rockburst," International Journal of Mining Science and Technology, vol. 24, no. 6, pp. 805-810, 2014.

[18] F. A. Ooriad, M. Yari, R. Bagherpour, and M. Khoshouei, "The development of a novel model for mining method selection in a fuzzy environment; case study; Tazareh coal mine, Semnan province, Iran," Rudarsko-Geološko-Naftni Zbornik, vol. 33, no. 1, pp. 45-53, 2018.

[19] W. J. Wang, C. Yuan, W. J. Yu et al., "Deformation control technology for surrounding rock reservation of deep high stress roadway," Journal of China Coal Society, vol. 41, no. 9, pp. 2156-2164, 2016.

[20] H. Yang, S. Cao, S. Wang, Y. Fan, S. Wang, and X. Chen, "Adaptation assessment of gob-side entry retaining based on geological factors," Engineering Geology, vol. 209, pp. 143-151, 2016.

[21] H. Basarir, I. Ferid Oge, and O. Aydin, "Prediction of the stresses around main and tail gates during top coal caving by 3D numerical analysis," International Journal of Rock Mechanics and Mining Sciences, vol. 76, pp. 88-97, 2015.

[22] D. W. Yang, Z. G. Ma, F. Z. Qi et al., "Optimization study on roof break direction of gob-side entry retaining by roof break and filling in thick-layer soft rock layer," Geomechanics and Engineering, vol. 13, no. 2, pp. 195-215, 2017.

[23] V. Popa, D. Cotofana, and R. Vacareanu, "Effective stiffness and displacement capacity of short reinforced concrete columns with low concrete quality," Bulletin of Earthquake Engineering, vol. 12, no. 6, pp. 2705-2721, 2014.

[24] A. S. Ranathunga, M. S. A. Perera, and P. G. Ranjith, "Deep coal seams as a greener energy source: a review," Journal of Geophysics and Engineering, vol. 11, no. 6, Article ID 063001, 2014.

[25] Q. H. Huang, Z. C. Hou, W. Z. Zhang, and P. Zhang, "Orthogonal experimental analysis of similar material cementing agent for clay aquifer," Journal of Mining and Safety Engineering, vol. 1, pp. 42-46, 2007. 


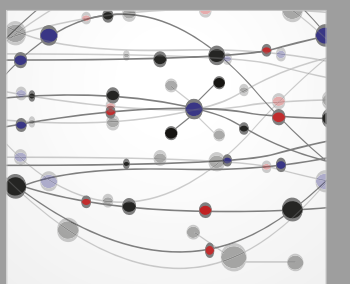

The Scientific World Journal
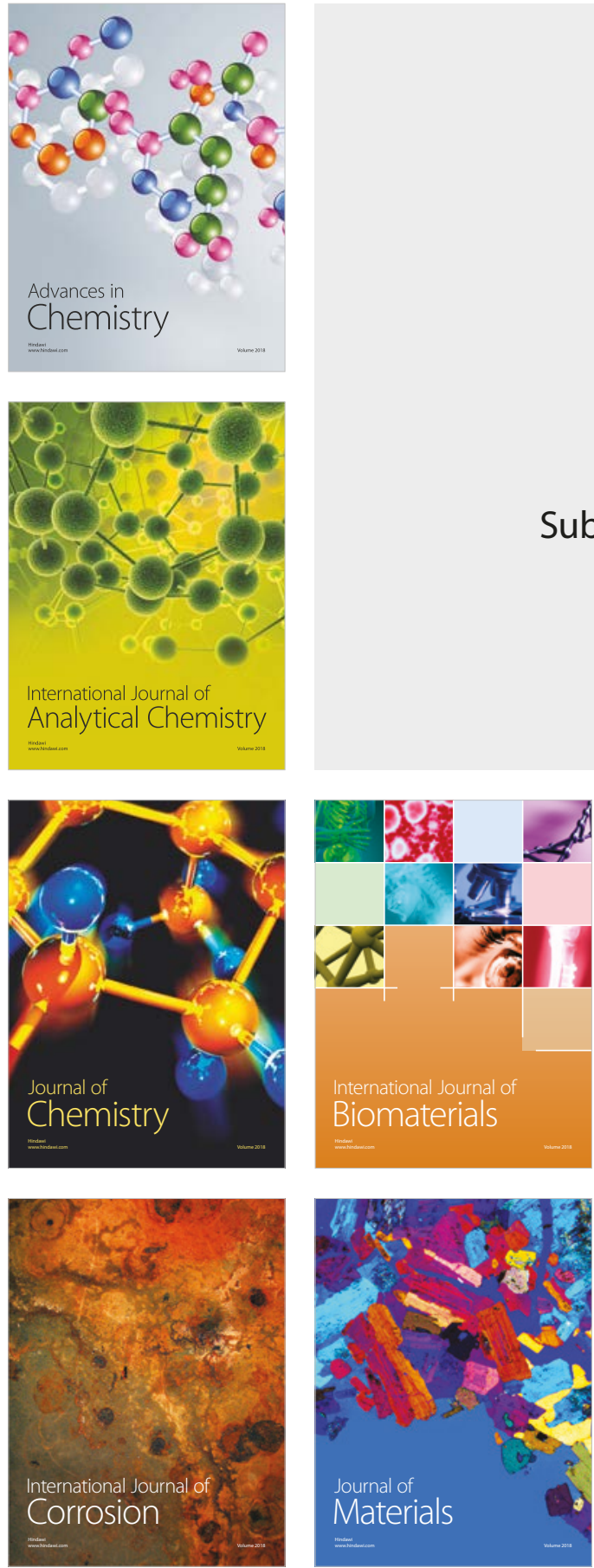

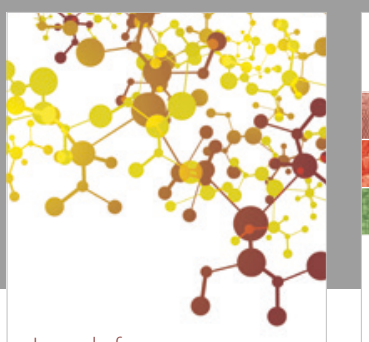

Journal of

Applied Chemistry
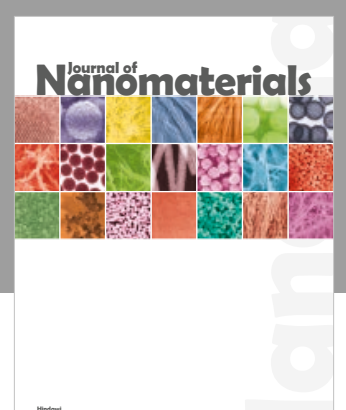

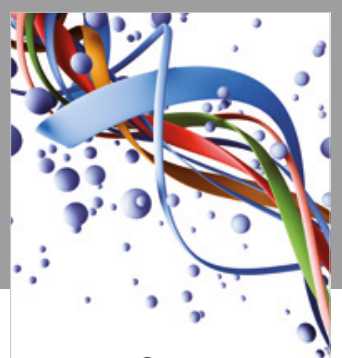

Scientifica

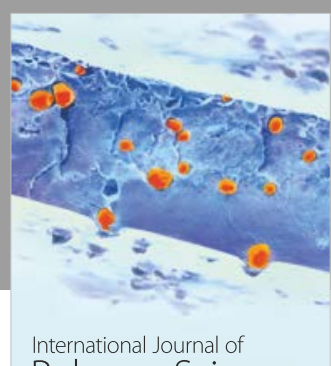

Polymer Science

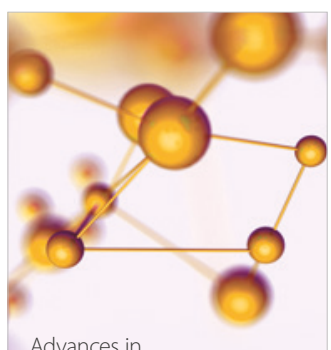

Physical Chemistry
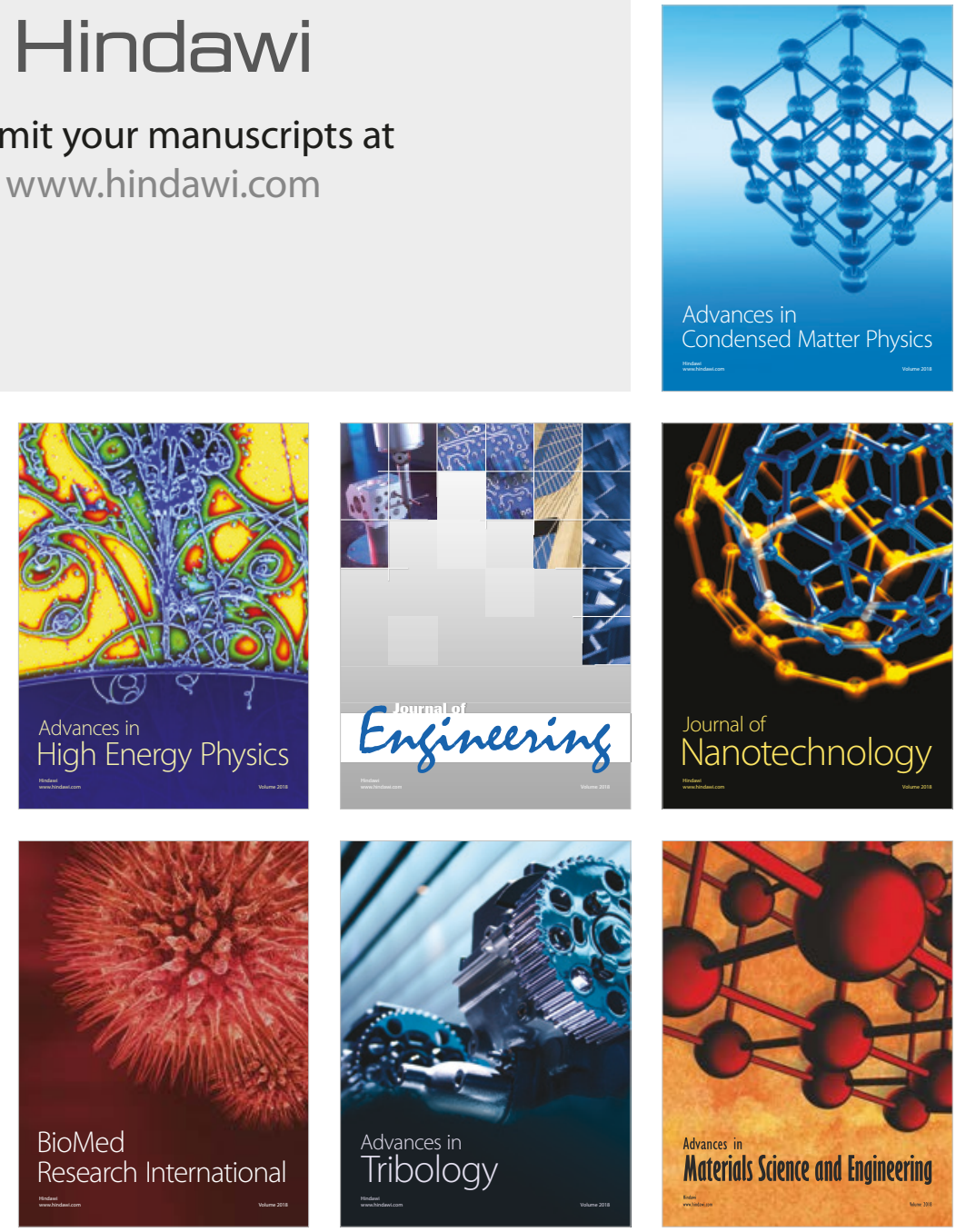